\title{
Article \\ Flavour Compensation Role of Yeast Strains in Reduced-Salt Dry Sausages: Taste and Odour Profiles
}

\author{
Xiang-Ao Li, Baohua Kong ${ }^{(}$, Rongxin Wen, Huiping Wang, Mengtong Li and Qian Chen * \\ College of Food Science, Northeast Agricultural University, Harbin 150030, China; lixiangao67@163.com (X.-A.L.); \\ kongbh63@hotmail.com (B.K.); wenrongxin810@163.com (R.W.); whp_1998@163.com (H.W.); \\ limengtong0923@163.com (M.L.) \\ * Correspondence: chenqianego7@126.com; Tel.: +86-451-55191794
}

Citation: Li, X.-A.; Kong, B.; Wen, R.; Wang, H.; Li, M.; Chen, Q. Flavour Compensation Role of Yeast Strains in Reduced-Salt Dry Sausages: Taste and Odour Profiles. Foods 2022, 11, 650. https://doi.org/10.3390/ foods 11050650

Academic Editor: María José Beriáin Apesteguía

Received: 16 January 2022

Accepted: 18 February 2022

Published: 23 February 2022

Publisher's Note: MDPI stays neutral with regard to jurisdictional claims in published maps and institutional affiliations.

Copyright: (C) 2022 by the authors. Licensee MDPI, Basel, Switzerland. This article is an open access article distributed under the terms and conditions of the Creative Commons Attribution (CC BY) license (https:// creativecommons.org/licenses/by/ $4.0 /)$.

\begin{abstract}
The effects of different yeast strains including Pichia kudriavzevii, Torulaspora delbrueckii, and Debaryomyces hansenii on the taste and odour profiles of reduced-salt dry sausages were explored. Inoculation of $P$. kudriavzevii and D. hansenii compensated for the lack of saltiness and umami tastes of reduced-salt sausages. Furthermore, inoculation of $P$. kudriavzevii and T. delbrueckii resulted in an odour profile in the reduced-salt dry sausages that was similar to traditional dry sausages. According to the volatile analysis, the contents of certain alcohols, acids, esters and terpenes were higher in the inoculated sausages. Finally, the sensory evaluation indicated that the inoculation of P. kudriavzevii and D. hansenii contributed positively to the aroma and saltiness of reduced-salt dry sausages. In conclusion, P. kudriavzevii and D. hansenii can be employed as effective starter cultures to compensate for the flavour deficiencies of reduced-salt dry sausages.
\end{abstract}

Keywords: dry sausage; salt reduction; yeast inoculation; flavour compensation; taste profile

\section{Introduction}

Salt (sodium chloride, $\mathrm{NaCl}$ ), an essential ingredient in meat products, plays a key role in providing saltiness, enhancing umami, creating desired textures, and prolonging shelf life [1-3]. Essential salt intake is required for normal body functions, however, excessive salt intake may increase the risk of hypertension, as well as cardiovascular, renal, and bone diseases [4,5]. Most people reportedly consume an average of 9-12 $\mathrm{g}$ of salt per day [6], which exceeds the recommended adult $\mathrm{NaCl}$ consumption limit ( $<5 \mathrm{~g} /$ day) established by the World Health Organization (WHO) [7]. Dry-cured meat products, especially dry sausages and dry-cured hams are among the primary sources of sodium intake, accounting for approximately $20 \%$ of the total intake [8]. In general, $2.5 \%$ of $\mathrm{NaCl}$ is added to dry sausages during their preparation. However, this level increases to 3.6-5\% after dehydration during fermentation [9]. Therefore, low-sodium dry sausages have recently garnered increasing attention [10-12].

Several strategies have been proposed for reducing the sodium content of meat products, such as directly reducing $\mathrm{NaCl}$ addition levels, replacing $\mathrm{NaCl}$ with chloride salts, and changing the physical structure of $\mathrm{NaCl}$, among others [13]. Among these, directly reducing $\mathrm{NaCl}$ addition is the most practical approach for both merchants and consumers, as it is less costly and avoids the undesirable flavours caused by chloride salts [14]. However, despite effectively reducing sodium intake, this strategy also negatively impacts the palatability and quality characteristics of meat products.

The application of appropriate starter cultures may be an alternative solution for reducing the salt level of fermented products, which can stabilize and standardize the fermentation process, enhance quality, and improve the safety of the final products [15]. Lactic acid bacteria (LAB) together with coagulase-negative staphylococci are the most common bacterial starter cultures in fermented meat products due to their contribution to the acidification process, colour development, and flavour formation [16]. Additionally, 
some fungi, such as yeasts also play a crucial role in fermented meat products. The yeast genera most frequently found in fermented meat products include Debaryomyces, Candida, Trichosporon, Pichia, Rhodotorula, Yarrowia, and Cryptococcus [17]. The quality of dry sausages can be enhanced through increasing $\mathrm{pH}$ via lactic acid utilization by yeast metabolism, stabilising the cured colour via antioxidant enzymes of yeasts [18,19], and promoting the flavour formation via the esterase and lipolytic and proteolytic enzymes of yeasts [20]. Further, yeast inoculation prevents the proliferation of harmful microorganisms, as well as mycotoxin accumulation [21]. Therefore, yeast strains could potentially compensate for the quality defects of reduced-salt dry sausages.

The flavour profile of dry sausages, including taste and odour properties, is a crucial indicator of their sensory characteristics. Free amino acids (FAAs), peptides, and organic acids, which originate from proteolysis and carbohydrate metabolism, play an important role in the taste and odour development of meat products [22]. Particularly, some FAAs and peptides provide saltiness and umami, and thus, may enhance the taste properties of reduced-salt dry sausages. In addition, the taste compensation role of some LAB strains has been confirmed in reduced-salt dry sausages [23]. Therefore, we hypothesised that yeasts could compensate for the flavour deficiencies of reduced-salt dry sausages.

In our previous study, 46 yeast strains were isolated from traditional dry sausages collected from Northeast China [24]. This type of dry sausage is a small calibre sausage subjected to a fast fermented process (approximately 12 days) and can be consumed after cooking. After evaluation, three strains (Pichia kudriavzevii, Torulaspora delbrueckii, and Debaryomyces hansenii) with excellent fermentation capabilities and flavour formation potential were selected for further characterization [25]. The effects of yeast inoculation on the physical, microbial, and quality characteristics of salt-reduced dry sausages were then investigated. The taste and odour properties of the resulting sausages were analysed via electronic tongue, electronic nose, and headspace solid-phase microextraction/gas chromatography-mass spectrometry (HS-SPME/GC-MS) in combination with partial least squares-discriminant analysis (PLS-DA) to evaluate the flavour compensation role of these yeast strains. This work will provide excellent starter cultures that can improve the quality and flavour characteristics of reduced-salt dry sausages.

\section{Materials and Methods}

\subsection{Preparation of Yeast Strains}

The flavour-enhancing properties of Pichia kudriavzevii, Torulaspora delbrueckii, and Debaryomyces hansenii were characterised in this study. These yeast strains were isolated from traditional dry sausages and identified via ITS (internal transcribed spacer) rRNA sequencing. All of them have been shown to be well resistant to environmental stress $(\mathrm{pH}$, sodium chloride and sodium nitrite) and have good flavour formation potential (proteolytic and lipolytic activities) in a fermented sausage model system. All yeast strains were inoculated $(2 \%, v / v)$ into fresh YPD (yeast extract peptone dextrose) medium and cultured for $24 \mathrm{~h}$ at $28^{\circ} \mathrm{C}$. After incubation, the yeast cultures were centrifuged at $6000 \times g$ for $10 \mathrm{~min}$ at $4{ }^{\circ} \mathrm{C}$ to collect cells. The cells were then washed twice with sterile saline solution and resuspended in $15 \mathrm{~mL}$ of sterile saline solution before use.

\subsection{Preparation of Dry Sausages}

Dry sausages were prepared as described by Hu et al. [10] with slight modifications. The sausages were manufactured with lean pork and pork back fat minced through a $1.5 \mathrm{~cm}$ plate with the following additives: salt, sodium nitrite, monosodium glutamate, dextrose, wine, ginger powder, and mixed spices. The mixed spices included fennel, nutmeg, cloves, cassia bark, angelica, orange peel, and Amomum villosum. The traditional dry sausage with $2.5 \% \mathrm{NaCl}(\mathrm{CT})$ and the reduced-salt dry sausage with $1.75 \% \mathrm{NaCl}(\mathrm{CR})$ were regarded as the control treatments for spontaneous fermentation. Three treatments with $1.75 \% \mathrm{NaCl}$ were inoculated with one of three starter cultures: P. kudriavzevii (PK), T. delbrueckii (TD), or 
D. hansenii $(\mathrm{DH})$. Each strain was inoculated in the minced meat and its inoculation level was approximately $10^{6} \mathrm{CFU} / \mathrm{g}$. The recipes and starter cultures are shown in Table 1.

Table 1. The recipes and starter cultures for different sausages.

\begin{tabular}{cccccc}
\hline & CT & CR & PK & TD & DH \\
\hline Starter cultures & - & - & P. kudriavzevii & T. delbrueckii & D. hansenii \\
Lean pork (g) & 5400 & 5400 & 5400 & 5400 & 5400 \\
Pork back fat (g) & 600 & 600 & 600 & 600 & 600 \\
Salt (g) & 150 & 105 & 105 & 105 & 105 \\
Sodium nitrite (g) & 0.54 & 0.54 & 0.54 & 0.54 & 0.54 \\
Monosodium glutamate (g) & 18 & 18 & 18 & 20 & 18 \\
Dextrose (g) & 20 & 20 & 20 & 60 & 20 \\
Wine (g) & 60 & 60 & 60 & 30 & 60 \\
Ginger powder (g) & 30 & 30 & 30 & 48 & 30 \\
Mixed spices (g) & 48 & 48 & 48 & 48
\end{tabular}

CT: $2.50 \% \mathrm{NaCl}$; CR: $1.75 \% \mathrm{NaCl}$; PK: $1.75 \% \mathrm{NaCl}+$ P. kudriavzevii; TD: $1.75 \% \mathrm{NaCl}+$ T. delbrueckii; $\mathrm{DH}: 1.75 \%$ $\mathrm{NaCl}+$ D. hansenii.

The meat was mixed with the ingredients and filled into natural porcine casings until each fresh sausage was approximately $20 \mathrm{~cm}$ long with a $2.5 \mathrm{~cm}$ diameter. The sausages were then allowed to air-dry naturally at $25 \pm 2{ }^{\circ} \mathrm{C}(30-50 \%$ relative humidity) for one day, then transferred to an incubator with the same temperature (65-75\% relative humidity) for eleven days. Three independent batches of dry sausages (replicates) were prepared, and 60 sausages were prepared in each batch. The raw sausages were subjected to physical, microbial, colour, and flavour analysis, and the cooked sausages were subjected to shear force analysis and sensory evaluation. Finally, 15 sausages were collected on days 0, 4, 8, and 12 for each time to measure various indicators immediately.

\subsection{Analysis of Physical, Microbial, and Quality Characteristics of Dry Sausages}

The sausages were minced in a grinder (HX-J3063, AUX, Ningbo, China) for moisture content and $\mathrm{pH}$ measurement. Moisture content was measured via the AOAC method [26] and $\mathrm{pH}$ was measured according to $\mathrm{Hu}$ et al. [27]. LAB and yeast counts were determined according to Wen et al. [28] and Bolumar et al. [29] with slight modifications. Five grams of sausages were homogenised in $45 \mathrm{~mL}$ of sterile saline and decimal dilutions were prepared in the same solution. LAB counts were determined in de Man-Rogosa-Sharpe (MRS) agar after incubation at $37^{\circ} \mathrm{C}$ for 2 days. Yeast counts were determined in YPD agar at $28{ }^{\circ} \mathrm{C}$ for 2 days. Shear force was determined using a texture analyser (Stable Micro Systems; TA-XT PLUS, Godalming, UK) coupled with the shear blade (Warner-Bratzler G146, Los Angeles, CA, USA) according to the method of $\mathrm{Hu}$ et al. [30]. The sausages were cooked at $90{ }^{\circ} \mathrm{C}$ for $20 \mathrm{~min}$ (core temperature $74^{\circ} \mathrm{C}$ ) and cooled to room temperature $\left(25^{\circ} \mathrm{C}\right)$, then were cut at least six cylinders of $20 \mathrm{~mm}$ thickness for each treatment. The shear force analysis parameters were set as follows: force sensor $(30 \mathrm{~kg})$, pre-test speed $2 \mathrm{~mm} / \mathrm{s}$, test speed $2 \mathrm{~mm} / \mathrm{s}$, post-test speed $2 \mathrm{~mm} / \mathrm{s}$, distance $8 \mathrm{~mm}$, trigger force $30 \mathrm{~g}$. The colour of sausages, characterised by the $L^{*}$-value, $a^{*}$-value, and $b^{*}$-value, was determined by a ZE-6000 colourimeter (Nippon Denshoku, Kogyo Co., Tokyo, Japan) with a $10^{\circ}$ observer and a D65 light source. The sausages were sliced, and the colour was measured on the cut surface in three different points of each sample. A white standard plate $\left(L^{*}=95.26\right.$, $a^{*}=-0.89, b^{*}=1.18$ ) was used for calibration prior to measurement [31].

\subsection{Electronic Nose Analysis}

The electronic nose analysis was performed using a PEN3 E-nose (Airsense Analytics $\mathrm{GmbH}$, Schwerin, Germany) as described by Zhang et al. [32] with slight modifications. Odours can be distinguished by ten sensors that generate responses based on the different chemical properties of volatiles, including W1C, W5S, W3C, W6S, W5C, W1S, W1W, W2S, $\mathrm{W} 2 \mathrm{~W}$, and $\mathrm{W} 3 \mathrm{~S}$ sensors and the information on these sensors is shown in Table 2. Minced 
dry sausage samples ( $3 \mathrm{~g}$ ) were placed in a 20-mL headspace vial and incubated for $45 \mathrm{~min}$ at $50{ }^{\circ} \mathrm{C}$. The electronic nose parameters were set as follows: chamber flow rate, $200 \mathrm{~mL} / \mathrm{min}$; injection flow rate, $200 \mathrm{~mL} / \mathrm{min}$; measurement duration, $120 \mathrm{~s}$. The sealed headspace bottle was punctured with a needle to absorb the volatiles from the headspace at a constant rate. The sensor array was purged with pure air as a carrier gas to return the signal response to zero.

Table 2. The information on ten electronic nose sensors.

\begin{tabular}{|c|c|c|}
\hline Sensor Name & $\begin{array}{l}\text { Representative } \\
\text { Substance Type }\end{array}$ & Description \\
\hline W1C & Aromatic & Sensitive to aromatic compounds \\
\hline W5S & Broad range & Sensitive to nitrogen oxides \\
\hline W3C & Aromatic & Sensitive to aroma, aromatic compounds \\
\hline W6S & Hydrogen & Sensitive to hydrides \\
\hline W5C & Arom-aliph & Sensitive to short-chain alkane aromatic compounds \\
\hline W1S & Broad-methane & Sensitive to methyl \\
\hline W1W & Sulphur-organic & Sensitive to sulphides \\
\hline W2S & Broad-alcohol & Sensitive to alcohol, aldehydes and ketones \\
\hline W2W & Sulph-chlor & Sensitive to organic sulphides \\
\hline W3S & Methane-aliph & Sensitive to long-chain alkanes \\
\hline
\end{tabular}

\subsection{Electronic Tongue Analysis}

The taste profiles of dry sausages were analysed by a TS-5000Z electronic tongue (Insent Company, Atsugi-Shi, Japan) with a wide-range selection of specific artificial lipid membrane sensors. Electronic tongue systems contain five chemical sensors: CA0 (sourness sensor), AE1 (astringency sensor), AAE (umami sensor), CT0 (saltiness sensor), and C00 (bitter sensor). For the analysis, $30 \mathrm{~g}$ of minced sausage samples were mixed with $150 \mathrm{~mL}$ of distilled water to extract the taste substances. The mixture was placed in a water bath at $40{ }^{\circ} \mathrm{C}$ for $30 \mathrm{~min}$, then centrifuged at $5000 \times \mathrm{g}$ for $10 \mathrm{~min}$. The electronic tongue was adjusted and calibrated according to the manufacturer's instructions before conducting the measurements at room temperature. The sensors were washed with distilled water for $30 \mathrm{~s}$ between each measurement to ensure the stability and accuracy of the results. Additionally, the sensors were checked to ensure that they were operating in the correct $\mathrm{mV}$ range before each measurement. The sensor was immersed in the sample solution for $30 \mathrm{~s}$ and six replicate measurements were performed on each sample.

\subsection{Volatile Compound Analysis}

The volatile compounds in dry sausages were extracted via an HS-SPME device (Supelco, Bellefonte, PA, USA) and analysed via GC-MS (GCMS-QP 2020 NX, Shimadzu Co., Kyoto, Japan) as described by Wen et al. [9]. A total of $3 \mathrm{~g}$ of minced sausage and $2 \mu \mathrm{L}$ of 1,2-dichlorobenzene $(100 \mathrm{mg} / \mathrm{L}$ in methanol), which was used as the internal standard (IS), were mixed in a 20-mL headspace vial (CNW Technologies, Duesseldorf, Germany) at $45^{\circ} \mathrm{C}$ for $25 \mathrm{~min}$ to equilibrate and then at $45^{\circ} \mathrm{C}$ for $30 \mathrm{~min}$ to be extracted with a polydimethylsiloxane/divinylbenzene/carboxen (PDMS/DVB/CAR)-coated SPME fibre. The volatiles in the fibre were then released by thermally desorbing at $230{ }^{\circ} \mathrm{C}$ for $3 \mathrm{~min}$ in the GC injector and analysed via GC-MS. The running program was as follows, GC oven was maintained at $40{ }^{\circ} \mathrm{C}$ for $3 \mathrm{~min}$, and then it raised to $200{ }^{\circ} \mathrm{C}$ at a degree of $5^{\circ} \mathrm{C} / \mathrm{min}$, and finally heated to $230{ }^{\circ} \mathrm{C}$ at $10{ }^{\circ} \mathrm{C} / \mathrm{min}$ to be kept for $4 \mathrm{~min}$. The ion source temperature was $230{ }^{\circ} \mathrm{C}$ and the mass spectrometer scanned masses were from m/z 45 to 500 . Volatile compounds were determined by comparison with the NIST 17 experimental mass spectra library and those reported in the Flavornet database (http:/ / www.flavornet.org/flavornet.html, accessed on 4 June 2021). Similarities greater than $90 \%$ were taken as identification results. Volatiles were semi-quantified by dividing the peak area of the target compounds by the peak area of the IS and multiplying this ratio by the initial concentration of the IS (expressed in $\mu \mathrm{g} / \mathrm{kg}$ ). 
The linear retention index (LRI) of the volatiles was determined by calculating the retention index relative to a series of standard alkanes (C9-C33).

\subsection{Sensory Evaluation}

Sensory evaluation was performed as described by Chen et al. [33] with some modifications. The sensory assessment team consisted of 20 faculty and graduate students (10 males and 10 females) with experience in sensory evaluation of fermented meat products. All panellists participated in discussions to clarify the reference for the quantitative descriptive analysis on colour, hardness, aroma, and taste attributes and were trained by these criterions. Taste attribute standards were prepared for the panellists to familiarize the taste attributes, including lactic acid $(10 \mathrm{mM})$, sodium chloride $(12 \mathrm{mM})$ and monosodium glutamate $(4 \mathrm{mM})$. The intensity or degree of each attribute was expressed by a seven-point descriptive scale from 1 (low intensity) to 7 (high intensity). Colour is defined as the intensity of red on the surface of the dry sausage slice $(1=$ light red; $7=$ dark red). Hardness is defined as the force required to compress the sausages with the molars $(1=$ extremely soft; $7=$ extremely hard). Aroma is defined as the intensity of the characteristic odour of the sausages $(1=$ weak dry sausage aroma; $7=$ strong dry sausage aroma). Sourness is defined as the typical taste of citric acid ( $1=$ light acid taste; $7=$ strong acid taste). Saltiness is defined as the typical taste of sodium chloride $(1=$ light salty taste; $7=$ strong salty taste). Umami is defined as the typical taste of monosodium glutamate ( $1=$ light umami; 7 = strong umami). All sausages fermented for 12 days were cut into small $2 \mathrm{~mm}$ thick slices after cooking at $90{ }^{\circ} \mathrm{C}$ for $20 \mathrm{~min}$ (core temperature $74{ }^{\circ} \mathrm{C}$ ) and served randomly on white plastic plates that were randomly coded with four digits. Prior to scoring, a "warm-up" sample was provided to prompt the panellists of the scoring range for each sensory attribute. Each panellist was required to take a $1 \mathrm{~min}$ break and provided with purified water to clear their palates while tasting different samples.

\subsection{Statistical Analysis}

Three independent batches of dry sausages (replicates) were manufactured, and five treatments in each batch were prepared. Each experiment except for shear force analysis was conducted three times (triplicate observations). The data were analysed using the General Linear Model procedure in the Statistix 8.1 software package (Analytical Software, St. Paul, MN, USA) and the results were expressed as the mean values \pm standard errors (SE). Analysis of variance (ANOVA) coupled with Tukey's multiple comparison test was used in this study to identify significant differences between samples $(p<0.05)$. Variation in physical, microbial, and quality characteristics were described via a mixed model, with the different treatments and fermentation times as fixed terms, and each replicate as a random term. For the electronic nose, electronic tongue, and volatile compound analysis, fixed terms for a mixed model included different treatments and fermentation times, and a random term was each replicate. For sensory evaluation, a fixed term for a mixed model included different treatments, and random terms included sausage and sensory panel (session number, tasting order and panellist number). Principal component analysis (PCA) was used to illustrate the relationship between the response values of the electronic nose and tongue analyses and their respective sensors using the Origin 2019 software (OriginLab Corporation, Northampton, MA, USA). PLS-DA of the volatile compounds was performed by an online platform called MetaboAnalyst 5.0 (https:/ /www.metaboanalyst.ca/, accessed on 13 December 2021). The variable importance in the projection (VIP) values were calculated based on the supervised PLS-DA model to determine the key differential volatile compounds.

\section{Results and Discussion}

\subsection{Physical, Microbial, and Quality Characteristic Analysis}

As depicted in Table 3, the moisture content in all dry sausages decreased significantly during fermentation $(p<0.05)$. After 12 days of fermentation, the moisture content de- 
creased from approximately $70.73 \%$ to $18.35 \%, 19.36 \%, 19.79 \%, 19.85 \%$, and $21.56 \%$ for the CT, CR, PK, TD, and DH treatments, respectively. The CT treatment exhibited a lower moisture content than the $\mathrm{CR}$ treatment, which was due to the different salt concentrations. The higher salt concentration may cause higher moisture evaporation [34]. The treatment inoculated with $D$. hansenii had the highest moisture content among all inoculated treatments on day $12(p<0.05)$. This phenomenon of delayed moisture content reduction was previously reported by Perea-Sanz et al. [35] who reported that the inoculation of $D$. hansenii could significantly increase the moisture content at the end of fermentation. Nevertheless, this phenomenon was not observed in the PK and TD treatments in our experiments, which may be due to the better ability of $D$. hansenii to accumulate $\mathrm{Na}^{+}$and maintain cation homeostasis to avoid the osmotic shock induced by a large amount of salt [25]. After 8 days of fermentation, the $\mathrm{pH}$ of dry sausages gradually decreased from approximately 6.09 to $5.59,5.40,5.16,5.07$, and 5.31 for the CT, CR, PK, TD, and DH treatments $(p<0.05)$. This may be due to the consumption of carbohydrates by the lactic acid bacteria, resulting in the accumulation of lactic acid. Moreover, on day 8, the $\mathrm{pH}$ of inoculated sausages was lower than those of the two controls, which may be because yeast inoculation makes carbohydrates easier to metabolise by lactic acid bacteria [8]. The $\mathrm{pH}$ of all sausages was steady from day 8 to day 12 , which may have been from the $\mathrm{NH}_{3}$, amines, and alkaline compounds produced by protein hydrolysis [36] and the decomposition of organic acids metabolised by yeast and fungi [37].

The yeast counts in the $\mathrm{CT}, \mathrm{CR}$, and TD treatments significantly increased from day 0 to day $8(p<0.05)$, and the $\mathrm{PK}$ and $\mathrm{DH}$ treatments significantly increased from day 0 to day $4(p<0.05)$. The LAB counts in the CT, CR, TD, and DH treatments significantly increased from day 0 to day $8(p<0.05)$, and the PK treatment significantly increased from day 0 to day $4(p<0.05)$. After reaching the maximum value, microbial counts decreased significantly $(p<0.05)$ in all treatments except for yeast counts in the CR treatment and LAB counts in the CT treatment. This may be attributed to the suitable environment at the early stage of fermentation; however, nutrient consumption and low moisture content continued as fermentation progressed. After 12 days of fermentation, there was no significant difference in the yeast count among the inoculated treatments $(p>0.05)$; however, yeast inoculation affected LAB growth. The LAB counts in the PK, TD, and DH treatments reached 7.56, 7.20, and $7.56 \log \mathrm{CFU} / \mathrm{g}$, respectively, whereas the $\mathrm{CR}$ treatment with the same salt content was $7.33 \log$ CFU/g. Different yeast species are known to interact differently with LAB [37]. In this study, T. delbrueckii inhibited LAB growth whereas P. kudriavzevii and D. hansenii promoted LAB growth.

The decreasing moisture content described above may be responsible for the significant increase in shear force during fermentation $(p<0.05)$. The inoculated sausages exhibited a significantly lower shear force than the controls $(p<0.05)$. On day 12 , the shear force of the $\mathrm{PK}, \mathrm{TD}$, and DH treatments reached $16.56,18.58$, and $16.59 \mathrm{~N}$, respectively, which was well below the values observed in the uninoculated CT $(26.05 \mathrm{~N})$ and CR $(20.57 \mathrm{~N})$ treatments. This was consistent with previous studies that reported that some yeasts could promote the degradation of myofibrillar proteins causing a decrease in shear force, particularly at the end of fermentation [38].

The $L^{*}$-values of all dry sausages showed a significant reduction after 8 days of fermentation $(p<0.05)$, and except for the PK treatment, the $L^{*}$-values of all treatments did not change from day 8 to $12(p>0.05)$. The decrease in the $L^{*}$-values may be associated with the aforementioned decrease in the moisture content. The thin aqueous layer on the surface of the meat was disrupted during sausage fermentation, thus, generating less light scattering and darkening the sausages [39]. This may also explain why the DH treatment had the highest $L^{*}$-values among all treatments on day $12(p<0.05)$. Additionally, the $a^{*}$-value of the PK treatment was significantly higher than that of the DH treatment on day $12(p<0.05)$, but it was not different from the controls and the TD treatment $(p>0.05)$. This is inconsistent with the results found in some studies that yeast exert a stabilising effect on reddening [40], which may be related to differences in product types and manufacturing 
processes [41]. Compared to day 0 , the increase in the $b^{*}$-values of each dry sausage after fermentation of 12 days may be related to lipid oxidation [42]. Concretely, the reaction between lipid oxidation products and amines in phospholipid head groups or the amines in protein may lead to yellow pigmentation [43]. In this study, neither the salt content nor the yeast inoculation affected the $b^{*}$-value on each fermentation time $(p>0.05)$.

Table 3. Changes in physical, microbial, and quality characteristics of the control and reduced-salt dry sausages with and without inoculation of different yeast strains during a 12-day fermentation period.

\begin{tabular}{|c|c|c|c|c|c|c|}
\hline & $\begin{array}{l}\text { Fermentation } \\
\text { Time (Day) }\end{array}$ & $\mathrm{CT}$ & CR & PK & TD & DH \\
\hline \multirow{4}{*}{$\begin{array}{l}\text { Moisture content } \\
\qquad(\%)\end{array}$} & 0 & $70.60 \pm 2.25 \mathrm{Aa}$ & $69.63 \pm 3.12 \mathrm{Aa}$ & $71.28 \pm 3.72 \mathrm{Aa}$ & $70.65 \pm 1.13^{\mathrm{Aa}}$ & $71.47 \pm 0.52 \mathrm{Aa}$ \\
\hline & 4 & $37.27 \pm 1.24 \mathrm{Bc}$ & $40.79 \pm 0.98^{\mathrm{Ba}}$ & $40.54 \pm 0.37^{\mathrm{Bab}}$ & $42.27 \pm 0.54 \mathrm{Ba}$ & $38.58 \pm 0.60^{\mathrm{Bbc}}$ \\
\hline & 8 & $22.89 \pm 0.28 \mathrm{Cc}$ & $25.81 \pm 0.16^{\mathrm{Cb}}$ & $25.77 \pm 0.70 \mathrm{Cb}$ & $25.63 \pm 0.25^{\mathrm{Cb}}$ & $27.46 \pm 0.19 \mathrm{Ca}$ \\
\hline & 12 & $18.35 \pm 0.04^{\mathrm{Dc}}$ & $19.36 \pm 0.32 \mathrm{Db}$ & $19.79 \pm 0.27^{\mathrm{Db}}$ & $19.85 \pm 0.19^{\mathrm{Db}}$ & $21.56 \pm 0.44^{\mathrm{Da}}$ \\
\hline \multirow{4}{*}{$\mathrm{pH}$} & 0 & $6.10 \pm 0.03 \mathrm{Aa}$ & $6.09 \pm 0.04 \mathrm{Aa}$ & $6.08 \pm 0.03 \mathrm{Aa}$ & $6.09 \pm 0.03 \mathrm{Aa}$ & $6.09 \pm 0.04^{\mathrm{Aa}}$ \\
\hline & 4 & $5.69 \pm 0.02 \mathrm{Ba}$ & $5.55 \pm 0.02^{\mathrm{Bb}}$ & $5.56 \pm 0.03^{\mathrm{Bb}}$ & $5.28 \pm 0.04^{\mathrm{Bc}}$ & $5.56 \pm 0.02^{\mathrm{Bb}}$ \\
\hline & 8 & $5.59 \pm 0.01 \mathrm{Ca}$ & $5.40 \pm 0.02 \mathrm{Cb}$ & $5.16 \pm 0.02 \mathrm{Cd}$ & $5.07 \pm 0.02 \mathrm{Ce}$ & $5.31 \pm 0.01 \mathrm{Cc}$ \\
\hline & 12 & $5.65 \pm 0.04^{\mathrm{BCa}}$ & $5.45 \pm 0.02 \mathrm{Cb}$ & $5.20 \pm 0.01 \mathrm{Cd}$ & $5.12 \pm 0.02 \mathrm{Ce}$ & $5.34 \pm 0.01^{\mathrm{Cc}}$ \\
\hline \multirow{4}{*}{$\begin{array}{l}\text { Yeast count } \\
(\log C F U / g)\end{array}$} & 0 & $4.80 \pm 0.02 \mathrm{Db}$ & $4.80 \pm 0.01 \mathrm{Cb}$ & $6.12 \pm 0.04 \mathrm{Ca}$ & $6.08 \pm 0.04 \mathrm{Da}$ & $6.07 \pm 0.04^{\mathrm{Da}}$ \\
\hline & 4 & $5.35 \pm 0.03 \mathrm{Ce}$ & $6.04 \pm 0.03^{\mathrm{Bd}}$ & $7.42 \pm 0.05^{\mathrm{Bc}}$ & $7.75 \pm 0.02 \mathrm{Aa}$ & $7.52 \pm 0.04^{\mathrm{Ab}}$ \\
\hline & 8 & $5.68 \pm 0.03 \mathrm{Ad}$ & $6.30 \pm 0.06 \mathrm{Ac}$ & $7.56 \pm 0.03^{\mathrm{Aa}}$ & $7.39 \pm 0.03^{\mathrm{Bb}}$ & $7.36 \pm 0.03^{\mathrm{Bb}}$ \\
\hline & 12 & $5.54 \pm 0.02 \mathrm{Bc}$ & $6.23 \pm 0.02^{\mathrm{Ab}}$ & $7.28 \pm 0.04^{\mathrm{Ba}}$ & $7.22 \pm 0.01 \mathrm{Ca}$ & $7.21 \pm 0.03 \mathrm{Ca}$ \\
\hline \multirow{4}{*}{$\begin{array}{l}\text { LAB count } \\
(\log C F U / g)\end{array}$} & 0 & $5.14 \pm 0.02 \mathrm{Ca}$ & $5.14 \pm 0.01 \mathrm{Da}$ & $5.15 \pm 0.01 \mathrm{Da}$ & $5.14 \pm 0.01 \mathrm{Ca}$ & $5.15 \pm 0.01^{\mathrm{Da}}$ \\
\hline & 4 & $6.86 \pm 0.01^{\mathrm{Bd}}$ & $6.93 \pm 0.01^{C c}$ & $7.25 \pm 0.02 \mathrm{Cb}$ & $7.42 \pm 0.02 \mathrm{Aa}$ & $7.24 \pm 0.02 \mathrm{Cb}$ \\
\hline & 8 & $7.09 \pm 0.06 \mathrm{Ae}$ & $7.45 \pm 0.03 \mathrm{Ac}$ & $7.81 \pm 0.02 \mathrm{Aa}$ & $7.35 \pm 0.03 \mathrm{Ad}$ & $7.65 \pm 0.02 \mathrm{Ab}$ \\
\hline & 12 & $7.04 \pm 0.04^{\mathrm{Ad}}$ & $7.33 \pm 0.03^{\mathrm{Bb}}$ & $7.56 \pm 0.03^{\mathrm{Ba}}$ & $7.20 \pm 0.05^{\mathrm{Bc}}$ & $7.56 \pm 0.02 \mathrm{Ba}$ \\
\hline \multirow{4}{*}{$\begin{array}{l}\text { Shear force } \\
(\mathrm{N})\end{array}$} & 0 & $3.03 \pm 0.18^{\mathrm{Da}}$ & $2.83 \pm 0.28^{\mathrm{Da}}$ & $2.82 \pm 0.12^{\mathrm{Da}}$ & $2.75 \pm 0.41^{\mathrm{Da}}$ & $3.33 \pm 0.15^{\mathrm{Da}}$ \\
\hline & 4 & $7.62 \pm 0.30 \mathrm{Ca}$ & $7.62 \pm 0.18 \mathrm{Ca}$ & $7.60 \pm 0.16 \mathrm{Ca}$ & $7.55 \pm 0.13 \mathrm{Ca}$ & $7.54 \pm 0.42 \mathrm{Ca}$ \\
\hline & 8 & $19.56 \pm 0.34^{\mathrm{Ba}}$ & $16.61 \pm 0.21^{\mathrm{Bb}}$ & $14.54 \pm 0.17^{\mathrm{Be}}$ & $15.90 \pm 0.14^{\mathrm{Bc}}$ & $15.17 \pm 0.13^{\mathrm{Bd}}$ \\
\hline & 12 & $26.05 \pm 0.79 \mathrm{Aa}$ & $20.57 \pm 0.26^{\mathrm{Ab}}$ & $16.56 \pm 0.34^{\mathrm{Ad}}$ & $18.58 \pm 0.21^{\mathrm{Ac}}$ & $16.59 \pm 0.18^{\mathrm{Ad}}$ \\
\hline \multirow{4}{*}{$L^{*}$-value } & 0 & $44.54 \pm 0.78 \mathrm{Aa}$ & $44.17 \pm 0.39 \mathrm{Aa}$ & $44.53 \pm 0.18^{\mathrm{Aa}}$ & $44.16 \pm 0.27 \mathrm{Aa}$ & $44.40 \pm 0.69 \mathrm{Aa}$ \\
\hline & 4 & $40.52 \pm 0.20^{\mathrm{Ba}}$ & $40.46 \pm 0.54 \mathrm{Ba}$ & $40.21 \pm 0.27 \mathrm{Ba}$ & $40.39 \pm 0.28^{\mathrm{Ba}}$ & $40.61 \pm 0.27$ Ва \\
\hline & 8 & $38.34 \pm 0.12$ Cc & $38.52 \pm 0.25 \mathrm{Cc}$ & $38.72 \pm 0.38 \mathrm{Cbc}$ & $39.60 \pm 0.43 \mathrm{Ca}$ & $39.47 \pm 0.26^{\mathrm{Cab}}$ \\
\hline & 12 & $38.13 \pm 0.09 \mathrm{Cb}$ & $38.39 \pm 0.09 \mathrm{Cb}$ & $38.21 \pm 0.23 \mathrm{Cb}$ & $38.14 \pm 0.13^{\mathrm{Db}}$ & $39.12 \pm 0.22 \mathrm{Ca}$ \\
\hline \multirow{4}{*}{$a^{*}$-value } & 0 & $11.48 \pm 0.33^{\mathrm{Da}}$ & $11.63 \pm 0.48^{\mathrm{Ca}}$ & $11.60 \pm 0.09 \mathrm{Da}$ & $11.67 \pm 0.07 \mathrm{Da}$ & $11.56 \pm 0.35 \mathrm{Ca}$ \\
\hline & 4 & $13.23 \pm 0.19 \mathrm{Ca}$ & $13.42 \pm 0.18^{\mathrm{Ba}}$ & $13.42 \pm 0.17 \mathrm{Ca}$ & $13.34 \pm 0.37 \mathrm{Ca}$ & $13.33 \pm 0.22^{\mathrm{Ba}}$ \\
\hline & 8 & $14.20 \pm 0.05^{\mathrm{Bb}}$ & $14.15 \pm 0.20 \mathrm{Bb}$ & $14.82 \pm 0.21^{\mathrm{Ba}}$ & $14.28 \pm 0.27 \mathrm{Bb}$ & $14.23 \pm 0.19 \mathrm{Ab}$ \\
\hline & 12 & $14.89 \pm 0.14^{\mathrm{Aab}}$ & $15.00 \pm 0.18 \mathrm{Aab}$ & $15.41 \pm 0.02 \mathrm{Aa}$ & $15.01 \pm 0.29 \mathrm{Aab}$ & $14.82 \pm 0.24^{\mathrm{Ab}}$ \\
\hline \multirow{4}{*}{$b^{*}$-value } & 0 & $15.37 \pm 0.17 \mathrm{Ca}$ & $15.33 \pm 0.12 \mathrm{Ca}$ & $15.31 \pm 0.21 \mathrm{Ca}$ & $15.39 \pm 0.13 \mathrm{Ca}$ & $15.34 \pm 0.11 \mathrm{Ca}$ \\
\hline & 4 & $17.46 \pm 0.51^{\mathrm{Ba}}$ & $17.38 \pm 0.34^{\mathrm{Ba}}$ & $17.22 \pm 0.23^{\mathrm{Ba}}$ & $17.36 \pm 0.39 \mathrm{Ba}$ & $17.42 \pm 0.28^{\mathrm{Ba}}$ \\
\hline & 8 & $17.62 \pm 0.10^{\mathrm{Aa}}$ & $17.78 \pm 0.14^{\mathrm{Ba}}$ & $17.53 \pm 0.23 \mathrm{Ba}$ & $17.48 \pm 0.18^{\mathrm{Ba}}$ & $17.75 \pm 0.16^{\mathrm{Ba}}$ \\
\hline & 12 & $18.32 \pm 0.14 \mathrm{Aa}$ & $18.39 \pm 0.14 \mathrm{Aa}$ & $18.37 \pm 0.17 \mathrm{Aa}$ & $18.44 \pm 0.17 \mathrm{Aa}$ & $18.46 \pm 0.29 \mathrm{Aa}$ \\
\hline
\end{tabular}

Different uppercase letters (A-D) within a column for the same indicator indicate significant differences among the different fermentation days $(p<0.05)$. Different lowercase letters $(\mathrm{a}-\mathrm{e})$ within a row for the same fermentation time indicate significant differences among the different treatments $(p<0.05)$. CT: $2.50 \% \mathrm{NaCl} ; \mathrm{CR}: 1.75 \% \mathrm{NaCl}$ PK: $1.75 \% \mathrm{NaCl}+$ P. kudriavzevii; TD: $1.75 \% \mathrm{NaCl}+$ T. delbrueckii; $\mathrm{DH}: 1.75 \% \mathrm{NaCl}+$ D. hansenii.

\subsection{Electronic Nose Analysis}

Electronic nose systems are a reliable means for identifying and distinguishing food odours. These devices detect volatile compounds as electronic signals and output them in digital form without having to classify all volatile substances into their individual components [44]. Table 4 illustrates the response value of each sensor upon analysing the dry sausages. Given that there were no significant differences among the five treatments on day 0 (based on the preliminary experiment and data not given), only one treatment (CT-0d) 
was used as a representative. After the 12-day fermentation period, all treatments exhibited significant increases in the response values of the W1C, W3C, and W5C sensors $(p<0.05)$ compared to those at the beginning of fermentation (day 0 ). This may be because moisture evaporation in the sausages during the fermentation process resulted in the concentration of volatile compounds. Specifically, fermentation contributes more aroma compounds to dry sausages, such as ammonia, short-chain alkanes, and aromatic compounds, thus increasing the response values. This observation was in accordance with the volatile compound results. Notably, the response values of the W1S sensor of the PK and DH treatments were significantly higher than those of the control, suggesting that P. kudriavzevii and D. hansenii inoculation could enhance the levels of volatile compounds with methyl groups in the reduced-salt dry sausages.

Table 4. Response values of electronic nose sensors of the control and reduced-salt dry sausages with and without yeast inoculation on days 0 and 12 .

\begin{tabular}{ccccccc}
\hline Sensor Name & CT-0d & CT-12d & CR-12d & PK-12d & TD-12d & DH-12d \\
\hline W1C & $0.14 \pm 0.04 \mathrm{~b}$ & $0.33 \pm 0.07^{\mathrm{a}}$ & $0.30 \pm 0.06^{\mathrm{a}}$ & $0.31 \pm 0.02^{\mathrm{a}}$ & $0.39 \pm 0.05^{\mathrm{a}}$ & $0.33 \pm 0.02^{\mathrm{a}}$ \\
W5S & $2.11 \pm 0.13^{\mathrm{a}}$ & $1.69 \pm 0.13^{\mathrm{b}}$ & $1.88 \pm 0.18^{\mathrm{ab}}$ & $1.76 \pm 0.08^{\mathrm{ab}}$ & $1.73 \pm 0.20^{\mathrm{ab}}$ & $1.95 \pm 0.11^{\mathrm{ab}}$ \\
W3C & $0.18 \pm 0.02 \mathrm{c}$ & $0.41 \pm 0.03^{\mathrm{ab}}$ & $0.38 \pm 0.02^{\mathrm{ab}}$ & $0.35 \pm 0.02^{\mathrm{b}}$ & $0.43 \pm 0.04^{\mathrm{a}}$ & $0.38 \pm 0.01^{\mathrm{ab}}$ \\
W6S & $8.67 \pm 2.65^{\mathrm{a}}$ & $3.67 \pm 0.68^{\mathrm{b}}$ & $4.22 \pm 0.72^{\mathrm{b}}$ & $3.90 \pm 0.24^{\mathrm{b}}$ & $3.47 \pm 0.47^{\mathrm{b}}$ & $4.20 \pm 0.27^{\mathrm{b}}$ \\
W5C & $0.24 \pm 0.03^{\mathrm{c}}$ & $0.58 \pm 0.03^{\mathrm{a}}$ & $0.53 \pm 0.03^{\mathrm{b}}$ & $0.47 \pm 0.03^{\mathrm{b}}$ & $0.58 \pm 0.04^{\mathrm{a}}$ & $0.53 \pm 0.01^{\mathrm{ab}}$ \\
W1S & $79.95 \pm 0.12^{\mathrm{a}}$ & $20.70 \pm 0.64^{\mathrm{e}}$ & $22.53 \pm 0.19^{\mathrm{d}}$ & $27.03 \pm 0.13^{\mathrm{b}}$ & $19.56 \pm 0.29^{\mathrm{f}}$ & $25.50 \pm 0.16^{\mathrm{c}}$ \\
W1W & $2.42 \pm 0.25^{\mathrm{ab}}$ & $1.72 \pm 0.11^{\mathrm{c}}$ & $1.84 \pm 0.12^{\mathrm{c}}$ & $1.78 \pm 0.07^{\mathrm{c}}$ & $1.77^{\mathrm{b}} \pm 0.10^{\mathrm{c}}$ & $1.93 \pm 0.06^{\mathrm{bc}}$ \\
W2S & $13.18 \pm 4.06^{\mathrm{a}}$ & $4.56 \pm 0.73^{\mathrm{b}}$ & $5.13 \pm 0.71^{\mathrm{b}}$ & $5.26 \pm 0.48^{\mathrm{b}}$ & $4.09 \pm 0.5^{\mathrm{b}}$ & $4.87^{\mathrm{b}} \pm 0.24^{\mathrm{b}}$ \\
W2W & $0.76 \pm 0.02^{\mathrm{a}}$ & $0.73 \pm 0.02^{\mathrm{abc}}$ & $0.70 \pm 0.01^{\mathrm{bc}}$ & $0.75 \pm 0.02^{\mathrm{ab}}$ & $0.72 \pm 0.01^{\mathrm{abc}}$ & $0.69 \pm 0.01^{\mathrm{c}}$ \\
W3S & $3.40 \pm 0.31^{\mathrm{a}}$ & $1.62 \pm 0.07^{\mathrm{b}}$ & $1.80 \pm 0.10^{\mathrm{b}}$ & $1.88 \pm 0.08^{\mathrm{b}}$ & $1.68 \pm 0.10^{\mathrm{b}}$ & $1.82^{\mathrm{b}} \pm 0.06^{\mathrm{b}}$ \\
\hline
\end{tabular}

Different lowercase letters (a-f) within a row indicate significant differences among the different treatments $(p<0.05)$. CT: $2.50 \% \mathrm{NaCl}$; CR: $1.75 \% \mathrm{NaCl}$; PK: $1.75 \% \mathrm{NaCl}+$ P. kudriavzevii; TD: $1.75 \% \mathrm{NaCl}+$ T. delbrueckii; DH: $1.75 \% \mathrm{NaCl}+$ D. hansenii.

The contribution of the first (PC1) and second (PC2) principal components were $89.0 \%$ and $9.5 \%$, respectively, thus explaining $98.5 \%$ of the total variation (Figure 1 ). The representative treatment on day 0 (CT-0d) was located in the positive axis of PC1, which was correlated with the W5S, W1W, W6S, W2S, W1S, W3S, and W2W sensors, whereas, all treatments at day 12 were located in the negative axis of PC1, which were correlated with the W5C, W3C, and W1C sensors. The PK and TD treatments were closer to the CT treatment, indicating that the overall odours of the PK and TD treatments were similar to the odour profile of traditional dry sausages.

\subsection{Electronic Tongue Analysis}

As illustrated in Figure 2A, the taste properties of dry sausages changed significantly after 12 days of fermentation $(p<0.05)$, compared to those of the CR treatment on day 0 , with increases in sourness, umami, and saltiness, and decreases in bitterness, aftertaste-B, and richness. The astringency and aftertaste-A (aftertaste-astringency) remained nearly unchanged compared to those of the CR treatment on day 0 . The increase in sourness can be explained by the acid production via the carbohydrate metabolism of LAB in sausages, which was consistent with the $\mathrm{pH}$ results [33]. Moreover, the DH treatment had a higher response value for saltiness than the CR treatment, but lower than the CT treatment on day $12(p<0.05)$. Further, the saltiness response value of the PK treatment on day 12 reached a similar level to that of the CT treatment on day $12(p>0.05)$, indicating that $P$. kudriavzevii and $D$. hansenii could enhance the saltiness of reduced-salt dry sausages. This saltiness enhancement was also observed by Ramos-Moreno et al. [45] when Iberian cured pork loin was inoculated with $D$. hansenii, which was explained by the ability of $D$. hansenii to accumulate high amounts of sodium from the environment without becoming intoxicated [41]. Additionally, the umami response value of the PK treatment on day 12 was higher than that of the CR treatment on day 12 , indicating that $P$. kudriavzevii could 
also enhance umami. This was probably due to the presence of umami amino acids and $5^{\prime}$ nucleotides in yeast strains [46].

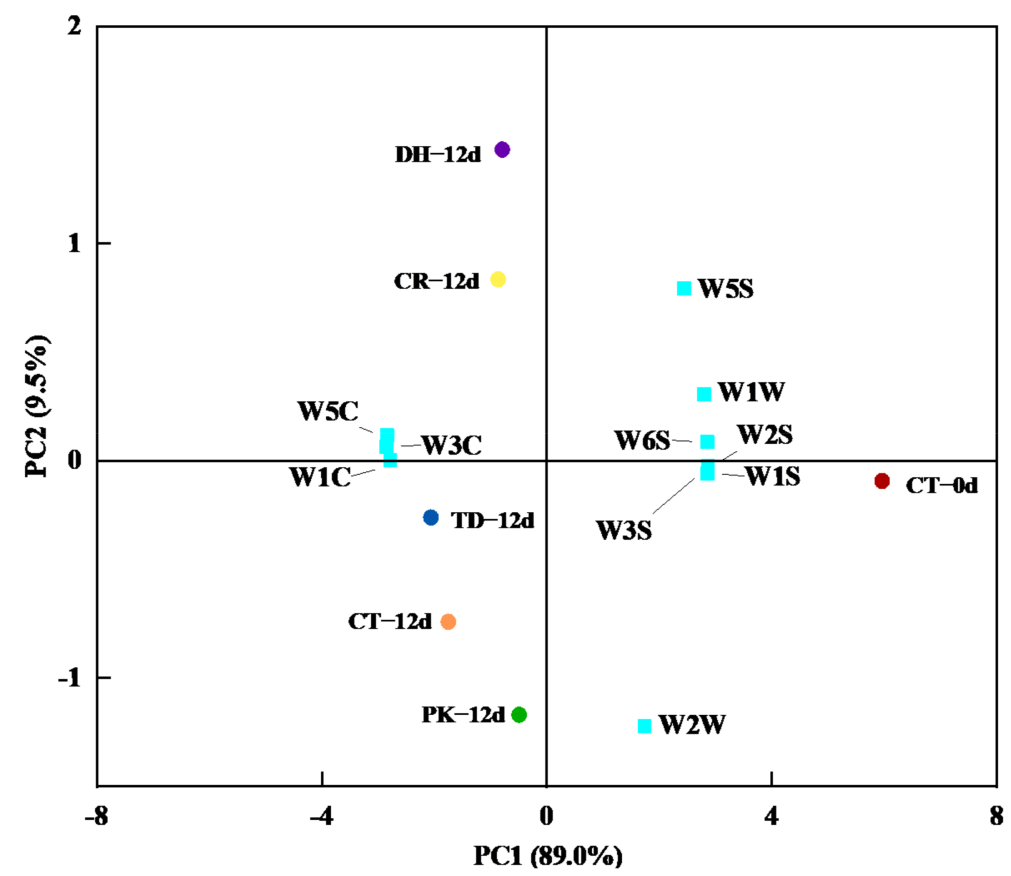

Figure 1. Principal component analysis of electronic nose data for the control and reduced-salt dry sausages with and without yeast inoculation on days 0 and 12. CT: $2.50 \% \mathrm{NaCl}$; CR: $1.75 \% \mathrm{NaCl}$; PK: $1.75 \% \mathrm{NaCl}+$ P. kudriavzevii; TD: $1.75 \% \mathrm{NaCl}+$ T. delbrueckii; $\mathrm{DH}: 1.75 \% \mathrm{NaCl}+$ D. hansenii.

(A)

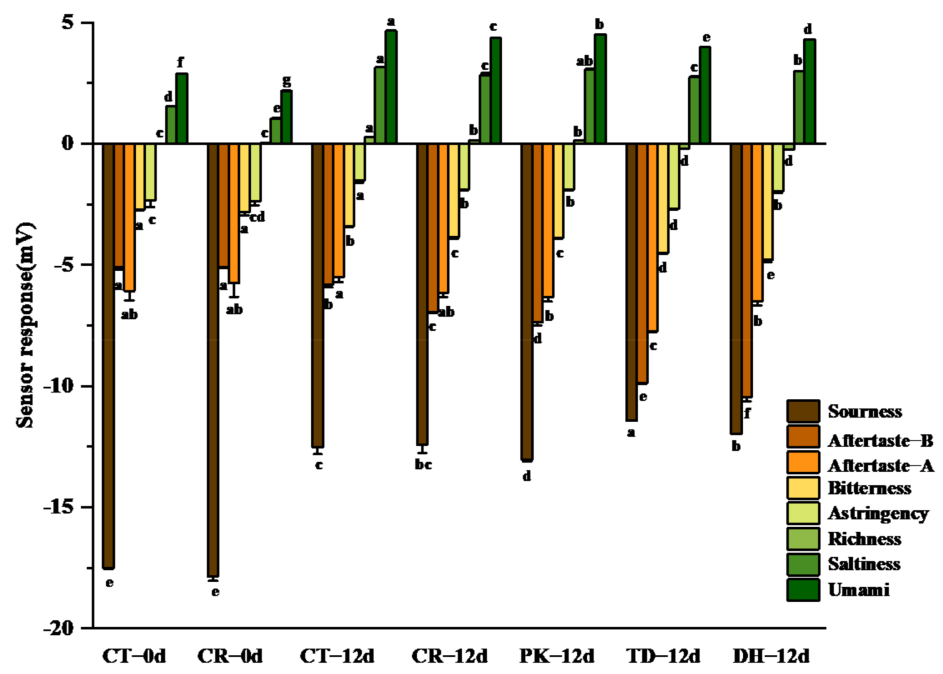

(B)

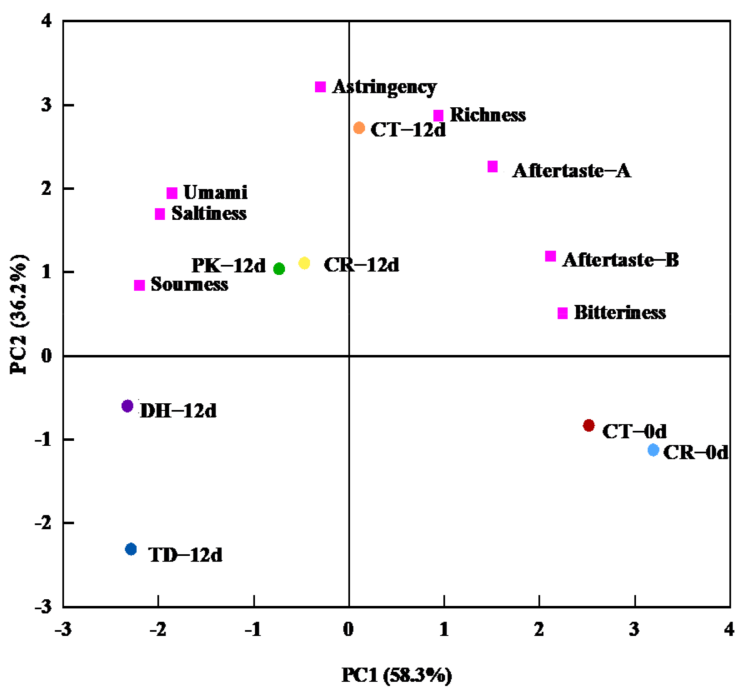

Figure 2. Column chart (A) and principal component analysis (B) of electronic tongue data for the control and reduced-salt dry sausages with and without yeast inoculation on days 0 and 12. CT: $2.50 \% \mathrm{NaCl}$; CR: $1.75 \% \mathrm{NaCl}$; PK: $1.75 \% \mathrm{NaCl}+$ P. kudriavzevii; TD: $1.75 \% \mathrm{NaCl}+$ T. delbrueckii; $\mathrm{DH}: 1.75 \% \mathrm{NaCl}+\mathrm{D}$. hansenii. Different lowercase letters $(\mathrm{a}-\mathrm{g})$ for the same taste attribute indicate significant differences among the different treatments $(p<0.05)$.

PCA was further performed using the data obtained from the electronic tongue analysis of the dry sausages. PC1 and PC2 explained 58.3\% and 36.2\% of the total variance, respectively, as illustrated in Figure 2B. The CT and CR treatments at day 0 were clustered 
in the fourth quadrant. After 12 days of fermentation, all treatments were dispersed in the first, second, and third quadrants, indicating that yeast inoculation significantly affected the overall taste profile. On day 12 , the CT treatment was associated with astringency, richness, and aftertaste-A, and the PK and CR treatments on day 12 were associated with umami, saltiness, and sourness. Among the inoculated dry sausages, the PK treatment was closer to the $\mathrm{CT}$ treatment than the $\mathrm{DH}$ and TD treatments, indicating that $P$. kudriavzevii inoculation rendered an overall flavour profile in the reduced-salt sausages that was similar to that of traditional dry sausages. Taken together, our findings indicate that $P$. kudriavzevii inoculation compensated for the lack of saltiness and umami flavours in reduced-salt dry sausages.

\subsection{Volatile Compound Analysis}

As shown in Table 5, 59 volatile compounds were detected in dry sausages, including aldehydes (4), ketones (5), alcohols (12), acids (6), esters (11), terpenes (15), and other compounds (6). These volatile compounds were derived from carbohydrate fermentation and the degradation of free amino acids and fatty acids, thus contributing to the unique flavour profile of dry sausages [47].

Table 5. Volatile compounds identified and quantified $(\mu \mathrm{g} / \mathrm{kg})$ by gas chromatography/mass spectrometry (GC-MS) of the control and reduced-salt dry sausages with and without yeast inoculation on days 0 and 12 .

\begin{tabular}{|c|c|c|c|c|c|c|c|c|c|}
\hline & $\begin{array}{l}\text { Volatile } \\
\text { Compound }\end{array}$ & CAS & LRI & CT-0d & CT-12d & CR-12d & PK-12d & TD-12d & DH-12d \\
\hline & Aldehydes & & & & & & & & \\
\hline V1 & Hexanal & $66-25-1$ & 1084 & n.d. & $8.58 \pm 0.30^{c}$ & $12.03 \pm 1.61^{\mathrm{c}}$ & $35.79 \pm 2.19^{a}$ & $11.93 \pm 0.38^{c}$ & $25.05 \pm 0.85^{b}$ \\
\hline $\mathrm{V} 2$ & Nonanal & $124-19-6$ & 1385 & $1.43 \pm 0.08^{\mathrm{e}}$ & $10.50 \pm 0.54^{c}$ & $16.25 \pm 1.40^{b}$ & $20.83 \pm 0.55^{\mathrm{a}}$ & $11.31 \pm 0.45^{c}$ & $7.74 \pm 0.55^{\mathrm{d}}$ \\
\hline V3 & Tridecanal & $10486-19-8$ & 1767 & $1.39 \pm 0.11^{\mathrm{e}}$ & $2.04 \pm 0.06^{\mathrm{d}}$ & $2.07 \pm 0.10^{d}$ & $3.77 \pm 0.16^{\mathrm{b}}$ & $3.02 \pm 0.18^{c}$ & $4.89 \pm 0.20^{a}$ \\
\hline \multirow[t]{2}{*}{$\mathrm{V} 4$} & Cinnamaldehyde & $104-55-2$ & 2170 & $9.48 \pm 0.51^{\mathrm{a}}$ & $3.52 \pm 0.10^{\mathrm{d}}$ & $2.08 \pm 0.06^{\mathrm{e}}$ & $4.41 \pm 0.13^{c}$ & $2.57 \pm 0.06^{\mathrm{e}}$ & $6.41 \pm 0.14^{\mathrm{b}}$ \\
\hline & Total & & & $12.30 \pm 0.18^{\mathrm{f}}$ & $24.64 \pm 0.16^{\mathrm{e}}$ & $32.43 \pm 0.33^{c}$ & $64.80 \pm 0.74^{\mathrm{a}}$ & $28.83 \pm 0.34^{\mathrm{d}}$ & $44.09 \pm 0.52^{b}$ \\
\hline & Ketones & & & & & & & & \\
\hline V5 & $\begin{array}{l}\text { 3-Hydroxy-2- } \\
\text { butanone }\end{array}$ & $513-86-0$ & 1299 & $3.86 \pm 0.10^{b}$ & $24.29 \pm 1.81^{\mathrm{a}}$ & $23.96 \pm 0.78^{a}$ & $23.19 \pm 0.33^{a}$ & $24.75 \pm 0.30^{\mathrm{a}}$ & $24.41 \pm 0.85^{\mathrm{a}}$ \\
\hline V6 & 2-Nonanone & $821-55-6$ & 1396 & $5.78 \pm 0.30^{\mathrm{a}}$ & $4.19 \pm 0.23^{c}$ & $3.30 \pm 0.18^{\mathrm{d}}$ & $4.11 \pm 0.27^{c}$ & $5.02 \pm 0.33^{b}$ & $4.16 \pm 0.21^{c}$ \\
\hline V7 & 2,3-Pentanedione & $600-14-6$ & 1120 & n.d. & n.d. & n.d. & $1.79 \pm 0.09^{\mathrm{a}}$ & n.d. & n.d. \\
\hline V8 & 1-Octen-3-one & $4312-99-6$ & 1283 & n.d. & n.d. & n.d. & $1.43 \pm 0.04^{b}$ & $1.57 \pm 0.06^{\mathrm{b}}$ & $2.09 \pm 0.07^{\mathrm{a}}$ \\
\hline \multirow[t]{2}{*}{ V9 } & $\begin{array}{l}\text { 6-Methyl-5-hepten- } \\
\text { 2-one }\end{array}$ & $110-93-0$ & 1544 & $17.20 \pm 0.66^{\mathrm{a}}$ & $9.47 \pm 0.45^{b}$ & $5.59 \pm 0.14^{c}$ & $3.82 \pm 0.16^{\mathrm{d}}$ & n.d. & n.d. \\
\hline & Total & & & $26.84 \pm 0.71^{c}$ & $37.95 \pm 2.21^{\mathrm{a}}$ & $32.85 \pm 1.19^{b}$ & $34.34 \pm 0.45^{\mathrm{ab}}$ & $31.34 \pm 0.79 \mathrm{bc}$ & $30.66 \pm 1.17^{b c}$ \\
\hline & Alcohols & & & & & & & & \\
\hline V10 & Ethanol & $64-17-5$ & 928 & $109.89 \pm 4.30^{b}$ & $67.16 \pm 0.95^{\mathrm{e}}$ & $69.72 \pm 1.15^{\mathrm{e}}$ & $80.14 \pm 1.23^{d}$ & $88.62 \pm 2.43^{c}$ & $143.23 \pm 3.45^{\mathrm{a}}$ \\
\hline V11 & 2,3-Butanediol & $513-85-9$ & 1590 & n.d. & $10.96 \pm 0.38^{c}$ & $24.50 \pm 1.16^{\mathrm{a}}$ & $25.29 \pm 1.61^{a}$ & $17.83 \pm 1.53^{b}$ & $26.96 \pm 1.92^{\mathrm{a}}$ \\
\hline V12 & 1-Octen-3-ol & $3391-86-4$ & 1451 & $0.77 \pm 0.06^{\mathrm{e}}$ & $3.10 \pm 0.16^{\mathrm{d}}$ & $3.15 \pm 0.16^{d}$ & $7.84 \pm 0.38^{a}$ & $4.66 \pm 0.20^{c}$ & $6.82 \pm 0.41^{b}$ \\
\hline V13 & 2-Heptanol & $543-49-7$ & 1285 & $2.30 \pm 0.16^{b c}$ & $2.07 \pm 0.23^{\mathrm{cd}}$ & $1.59 \pm 0.08^{\mathrm{e}}$ & $2.52 \pm 0.07^{\mathrm{b}}$ & $1.87 \pm 0.04 \mathrm{de}$ & $3.05 \pm 0.14^{\mathrm{a}}$ \\
\hline V14 & $\begin{array}{l}\text { 3-Phenyl-1- } \\
\text { propanol }\end{array}$ & $122-97-4$ & 1715 & $6.00 \pm 0.21^{\mathrm{a}}$ & n.d. & n.d. & n.d. & n.d. & n.d. \\
\hline V15 & Benzyl alcohol & $100-51-6$ & 1618 & n.d. & $5.58 \pm 0.24^{\mathrm{a}}$ & $3.18 \pm 0.13^{c}$ & $3.78 \pm 0.11^{b}$ & $5.46 \pm 0.20^{\mathrm{a}}$ & $3.51 \pm 0.08^{b c}$ \\
\hline V16 & Decyl alcohol & $112-30-1$ & 1300 & n.d. & n.d. & n.d. & n.d. & n.d. & $14.39 \pm 1.37^{\mathrm{a}}$ \\
\hline V17 & Cineole & $470-82-6$ & 1224 & $120.64 \pm 4.65^{\mathrm{a}}$ & $82.64 \pm 2.28^{c}$ & $66.79 \pm 1.92^{\mathrm{d}}$ & $92.12 \pm 3.86^{b}$ & $83.14 \pm 2.94 b c$ & $75.24 \pm 3.69^{\mathrm{cd}}$ \\
\hline V18 & Linalool & $78-70-6$ & 1552 & $117.24 \pm 3.41^{b c}$ & $119.31 \pm 3.82^{b}$ & $101.63 \pm 4.92^{\mathrm{d}}$ & $126.70 \pm 3.28^{b}$ & $107.17 \pm 3.35^{\mathrm{cd}}$ & $168.38 \pm 3.78^{a}$ \\
\hline V19 & Geraniol & 106-24-1 & 1849 & $5.12 \pm 0.16^{\mathrm{bc}}$ & $8.99 \pm 0.83^{\mathrm{a}}$ & $5.25 \pm 0.69 \mathrm{bc}$ & $4.07 \pm 0.31^{\mathrm{c}}$ & $4.00 \pm 0.25^{\mathrm{c}}$ & $6.44 \pm 0.51^{b}$ \\
\hline V20 & $(-)-\alpha$-Terpineol & $10482-56-1$ & 1517 & $22.59 \pm 1.32^{\mathrm{a}}$ & $12.92 \pm 0.69^{c}$ & $9.91 \pm 0.44^{\mathrm{d}}$ & $12.48 \pm 0.75^{\mathrm{c}}$ & $11.60 \pm 0.57^{\mathrm{cd}}$ & $16.21 \pm 1.16^{b}$ \\
\hline \multirow[t]{3}{*}{$\mathrm{V} 21$} & (-)-Terpinen-4-ol & $20126-76-5$ & 1466 & $44.14 \pm 2.09^{b}$ & $37.81 \pm 1.71^{\mathrm{cd}}$ & $30.07 \pm 0.98^{\mathrm{e}}$ & $40.04 \pm 1.19 b^{c}$ & $35.83 \pm 1.34^{\mathrm{d}}$ & $51.78 \pm 1.43^{\mathrm{a}}$ \\
\hline & Total & & & $428.69 \pm 4.78^{b}$ & $350.54 \pm 6.29^{d}$ & $315.79 \pm 5.89^{e}$ & $394.98 \pm 6.75^{c}$ & $360.18 \pm 4.21^{\mathrm{d}}$ & $516.01 \pm 7.81^{\mathrm{a}}$ \\
\hline & Acids & & & & & & & & \\
\hline V22 & Acetic acid & $64-19-7$ & 1450 & $5.49 \pm 0.48^{\mathrm{e}}$ & $90.27 \pm 1.81^{\mathrm{d}}$ & $183.34 \pm 4.85^{\mathrm{bc}}$ & $191.23 \pm 5.63^{b}$ & $171.00 \pm 5.32^{c}$ & $227.66 \pm 5.94^{\mathrm{a}}$ \\
\hline V23 & Isovaleric acid & $503-74-2$ & 1665 & $2.48 \pm 0.18^{c}$ & $5.15 \pm 0.41^{b}$ & $5.39 \pm 0.35^{\mathrm{b}}$ & $6.37 \pm 0.81^{\mathrm{b}}$ & $6.41 \pm 0.76^{\mathrm{b}}$ & $9.23 \pm 0.88^{\mathrm{a}}$ \\
\hline V24 & Heptanoic acid & $111-14-8$ & 2168 & n.d. & $2.22 \pm 0.33^{c}$ & $1.24 \pm 0.16^{c}$ & $4.82 \pm 0.57^{b}$ & $6.26 \pm 0.64^{b}$ & $15.06 \pm 0.92^{a}$ \\
\hline V25 & Nonanoic acid & $112-05-0$ & 2202 & $0.88 \pm 0.10^{c}$ & $1.28 \pm 0.18^{c}$ & $1.30 \pm 0.13^{c}$ & $2.94 \pm 0.20^{b}$ & $0.92 \pm 0.07^{c}$ & $3.73 \pm 0.23^{a}$ \\
\hline V26 & Butanoic acid & $107-92-6$ & 1477 & $3.62 \pm 0.18^{\mathrm{e}}$ & $4.92 \pm 0.42$ de & $6.80 \pm 0.25^{b c}$ & $8.53 \pm 0.61^{b}$ & $6.41 \pm 0.82^{\mathrm{cd}}$ & $12.18 \pm 1.17^{\mathrm{a}}$ \\
\hline \multirow[t]{2}{*}{ V27 } & Octanoic acid & $124-07-2$ & 2083 & n.d. & $8.57 \pm 0.45^{b}$ & $8.18 \pm 0.71^{\mathrm{b}}$ & $8.61 \pm 0.76^{\mathrm{b}}$ & $10.11 \pm 0.86^{\mathrm{b}}$ & $18.75 \pm 1.19^{\mathrm{a}}$ \\
\hline & Total & & & $12.47 \pm 0.37^{\mathrm{e}}$ & $112.41 \pm 4.30^{\mathrm{d}}$ & $206.25 \pm 6.01 b^{c}$ & $222.50 \pm 6.82^{b}$ & $201.11 \pm 3.63^{c}$ & $286.61 \pm 7.45^{\mathrm{a}}$ \\
\hline
\end{tabular}


Table 5. Cont.

\begin{tabular}{|c|c|c|c|c|c|c|c|c|c|}
\hline & $\begin{array}{l}\text { Volatile } \\
\text { Compound }\end{array}$ & CAS & LRI & CT-0d & CT-12d & CR-12d & PK-12d & TD-12d & DH-12d \\
\hline & Esters & & & & & & & & \\
\hline V28 & Ethyl acetate & $141-78-6$ & 907 & $1.21 \pm 0.13^{\mathrm{d}}$ & $4.07 \pm 0.25^{\mathrm{d}}$ & $18.45 \pm 0.93^{b}$ & $16.34 \pm 0.99^{b}$ & $23.12 \pm 1.12^{\mathrm{a}}$ & $11.87 \pm 0.66^{c}$ \\
\hline V29 & Ethyl lactate & $97-64-3$ & 1358 & n.d. & n.d. & $5.13 \pm 0.44^{c}$ & $20.27 \pm 0.76^{b}$ & $21.42 \pm 0.85^{b}$ & $32.52 \pm 0.61^{a}$ \\
\hline V30 & Methyl butyrate & $623-42-7$ & 963 & n.d. & n.d. & n.d. & $7.84 \pm 0.52^{b}$ & $1.05 \pm 0.08^{c}$ & $9.31 \pm 0.68^{a}$ \\
\hline V31 & Ethyl butyrate & $105-54-4$ & 1028 & n.d. & $2.92 \pm 0.35^{c}$ & $3.94 \pm 0.44 \mathrm{bc}$ & $4.53 \pm 0.28^{b}$ & $4.26 \pm 0.40^{b c}$ & $12.14 \pm 0.88^{a}$ \\
\hline V32 & Methyl hexanoate & $106-70-7$ & 1188 & $13.66 \pm 0.59^{\mathrm{d}}$ & $25.62 \pm 0.99^{c}$ & $39.92 \pm 1.34^{b}$ & $43.47 \pm 1.63^{b}$ & $28.98 \pm 1.46^{c}$ & $64.29 \pm 2.26^{a}$ \\
\hline V33 & Ethyl hexanoate & $123-66-0$ & 1120 & $18.71 \pm 0.72 \mathrm{e}^{\mathrm{e}}$ & $51.85 \pm 2.29^{c}$ & $42.34 \pm 1.34^{\mathrm{d}}$ & $74.67 \pm 1.43^{b}$ & $72.45 \pm 1.67^{b}$ & $159.18 \pm 3.78^{\mathrm{a}}$ \\
\hline V34 & Ethyl heptanoate & $106-30-9$ & 1328 & $1.08 \pm 0.17^{\mathrm{b}}$ & $3.30 \pm 0.37^{\mathrm{a}}$ & $2.71 \pm 0.38^{\mathrm{a}}$ & n.d. & $3.01 \pm 0.42^{\mathrm{a}}$ & n.d. \\
\hline V35 & Ethyl caprylate & $106-32-1$ & 1437 & $1.43 \pm 0.23^{\mathrm{d}}$ & $6.59 \pm 0.54^{c}$ & $7.59 \pm 0.61^{c}$ & $10.08 \pm 0.82^{b}$ & $11.36 \pm 0.59^{b}$ & $20.04 \pm 1.00^{\mathrm{a}}$ \\
\hline V36 & Bornyl acetate & $76-49-3$ & 1288 & $10.92 \pm 0.41^{\mathrm{c}}$ & $12.30 \pm 0.48^{\mathrm{abc}}$ & $9.09 \pm 0.59 \mathrm{~d}$ & $11.57 \pm 0.64 \mathrm{bc}$ & $13.53 \pm 0.57^{\mathrm{a}}$ & $13.19 \pm 0.93^{\mathrm{ab}}$ \\
\hline V37 & Ethyl caprate & $110-38-3$ & 1634 & n.d. & $5.18 \pm 0.47^{\mathrm{c}}$ & $5.73 \pm 0.55^{c}$ & $6.16 \pm 0.50^{c}$ & $8.40 \pm 0.96^{b}$ & $11.22 \pm 0.96^{\mathrm{a}}$ \\
\hline \multirow[t]{3}{*}{ V38 } & Methyl lactate & $547-64-8$ & 1293 & n.d. & $0.96 \pm 0.08^{c}$ & $4.14 \pm 0.44^{\mathrm{b}}$ & n.d. & $5.19 \pm 0.31^{\mathrm{b}}$ & $6.68 \pm 0.72^{\mathrm{a}}$ \\
\hline & Total & & & $47.01 \pm 1.74^{\mathrm{e}}$ & $112.79 \pm 3.49^{\mathrm{d}}$ & $139.04 \pm 0.98^{c}$ & $194.93 \pm 3.56^{b}$ & $192.77 \pm 2.96^{b}$ & $340.44 \pm 5.98^{a}$ \\
\hline & Terpenes & & & & & & & & \\
\hline V39 & Sabinene & $3387-41-5$ & 1160 & $2.84 \pm 0.52^{c}$ & $11.25 \pm 0.92^{b}$ & $8.43 \pm 0.95^{b}$ & $10.71 \pm 1.13^{b}$ & $11.02 \pm 0.86^{b}$ & $15.31 \pm 0.93^{\mathrm{a}}$ \\
\hline V40 & Myrcene & $123-35-3$ & 1145 & $8.38 \pm 0.75^{b}$ & $12.34 \pm 0.93^{\mathrm{a}}$ & $7.84 \pm 0.98^{b}$ & $9.31 \pm 1.17^{\mathrm{b}}$ & $12.09 \pm 1.09^{\mathrm{a}}$ & $12.17 \pm 0.95^{\mathrm{a}}$ \\
\hline V41 & (+)-Dipentene & $5989-27-5$ & 1203 & $76.70 \pm 3.11^{\mathrm{e}}$ & $174.82 \pm 6.01^{\mathrm{ab}}$ & $126.56 \pm 5.16^{\mathrm{d}}$ & $152.97 \pm 4.27^{\mathrm{c}}$ & $181.89 \pm 4.51^{\mathrm{a}}$ & $162.42 \pm 4.45 b^{c}$ \\
\hline V42 & $\gamma$-Terpinene & $99-85-4$ & 1178 & $15.05 \pm 0.54^{\mathrm{f}}$ & $35.65 \pm 0.62^{b}$ & $22.08 \pm 0.27^{\mathrm{e}}$ & $25.18 \pm 0.33^{d}$ & $34.10 \pm 0.44^{\mathrm{c}}$ & $43.34 \pm 0.54^{\mathrm{a}}$ \\
\hline V43 & $\alpha$-Caryophyllene & $6753-98-6$ & 2209 & $8.66 \pm 0.51^{b c}$ & $3.12 \pm 0.31^{\mathrm{e}}$ & $7.04 \pm 0.59^{\mathrm{d}}$ & $7.73 \pm 0.55^{\mathrm{cd}}$ & $10.36 \pm 0.79^{a}$ & $10.04 \pm 0.30^{\mathrm{ab}}$ \\
\hline V44 & $\alpha$-Curcumene & $644-30-4$ & 1773 & $80.18 \pm 3.47^{a}$ & $63.90 \pm 1.53^{b}$ & $40.78 \pm 0.76^{c}$ & $45.22 \pm 1.10^{c}$ & $60.45 \pm 1.98^{b}$ & $64.78 \pm 1.46^{\mathrm{b}}$ \\
\hline V45 & $\alpha$-Farnesene & $502-61-4$ & 1543 & $18.50 \pm 0.79^{a}$ & $14.98 \pm 0.50^{b}$ & $9.44 \pm 0.81^{c}$ & $9.43 \pm 0.61^{c}$ & $14.38 \pm 0.83^{b}$ & $14.33 \pm 0.88^{b}$ \\
\hline V46 & $\alpha$-Terpinene & $99-86-5$ & 1282 & $4.21 \pm 0.44^{b}$ & $6.12 \pm 0.55^{\mathrm{a}}$ & $4.50 \pm 0.68^{b}$ & $4.13 \pm 0.25^{\mathrm{b}}$ & $5.24 \pm 0.72 \mathrm{ab}$ & $4.51 \pm 0.68^{b}$ \\
\hline V47 & $\beta$-Bisabolene & $495-61-4$ & 1536 & $23.70 \pm 1.95^{\mathrm{a}}$ & $17.96 \pm 0.81^{b}$ & $11.52 \pm 0.60^{c}$ & $11.99 \pm 0.45^{c}$ & $17.52 \pm 0.91^{b}$ & $17.33 \pm 0.83^{b}$ \\
\hline $\mathrm{V} 48$ & $\beta$-Caryophyllene & $87-44-5$ & 1594 & $57.39 \pm 1.61^{c}$ & $82.40 \pm 2.28^{a}$ & $54.82 \pm 1.54^{c}$ & $65.7 \pm 1.70^{\mathrm{b}}$ & $79.08 \pm 1.34^{\mathrm{a}}$ & $83.45 \pm 1.60^{\mathrm{a}}$ \\
\hline V49 & $\beta$-Famesene & $18794-84-8$ & 1661 & $2.29 \pm 0.20^{\mathrm{d}}$ & $2.51 \pm 0.51^{\mathrm{d}}$ & $3.19 \pm 0.14^{\mathrm{cd}}$ & $4.58 \pm 0.45^{b}$ & $3.78 \pm 0.35 b^{c}$ & $6.62 \pm 0.55^{\mathrm{a}}$ \\
\hline V50 & (1 S)-(1)- $\beta$-Pinene & $18172-67-3$ & 1152 & $1.83 \pm 0.18^{\mathrm{d}}$ & $5.20 \pm 0.17^{b}$ & $3.76 \pm 0.47^{c}$ & $5.10 \pm 0.25^{b}$ & $5.22 \pm 0.23^{b}$ & $6.36 \pm 0.34^{\mathrm{a}}$ \\
\hline V51 & 3-Carene & $13466-78-9$ & 1146 & $1.32 \pm 0.18^{c}$ & $3.09 \pm 0.27 \mathrm{ab}$ & $2.51 \pm 0.25^{b}$ & $3.12 \pm 0.40^{a b}$ & $3.61 \pm 0.21^{\mathrm{a}}$ & $3.09 \pm 0.28 \mathrm{ab}$ \\
\hline V52 & Camphene & $79-92-5$ & 1705 & $9.35 \pm 0.65^{\mathrm{a}}$ & $4.00 \pm 0.51^{b}$ & $3.20 \pm 0.27^{b}$ & $3.59 \pm 0.21^{b}$ & $4.10 \pm 0.42^{b}$ & $9.99 \pm 1.12^{\mathrm{a}}$ \\
\hline \multirow[t]{3}{*}{ V53 } & Cyclosativene & $22469-52-9$ & 1373 & $3.14 \pm 0.23^{\mathrm{b}}$ & $3.75 \pm 0.34^{\mathrm{b}}$ & $3.05 \pm 0.52^{\mathrm{b}}$ & $3.93 \pm 0.40^{\mathrm{b}}$ & $4.08 \pm 0.45^{\mathrm{b}}$ & $5.42 \pm 0.62^{\mathrm{a}}$ \\
\hline & Total & & & $325.40 \pm 5.15^{c}$ & $453.54 \pm 7.54^{\mathrm{a}}$ & $316.05 \pm 2.63^{c}$ & $407.91 \pm 5.97^{b}$ & $457.38 \pm 6.22^{\mathrm{a}}$ & $470.86 \pm 7.16^{\mathrm{a}}$ \\
\hline & Others & & & & & & & & \\
\hline V54 & D-Camphor & $464-49-3$ & 1427 & $12.34 \pm 0.24 \mathrm{f}$ & $17.03 \pm 0.20^{\mathrm{d}}$ & $15.33 \pm 0.41^{\mathrm{e}}$ & $25.08 \pm 0.61^{b}$ & $18.97 \pm 0.54^{\mathrm{c}}$ & $27.64 \pm 0.34^{\mathrm{a}}$ \\
\hline V55 & 4-Allylanisole & $140-67-0$ & 1655 & $164.56 \pm 4.45^{\mathrm{b}}$ & $161.06 \pm 4.14^{b}$ & $108.28 \pm 2.45^{d}$ & $129.21 \pm 2.56^{d}$ & $146.72 \pm 2.23^{c}$ & $188.07 \pm 4.21^{\mathrm{a}}$ \\
\hline V56 & Anethole & $104-46-1$ & 1595 & $315.01 \pm 11.00^{b}$ & $246.66 \pm 8.66^{d}$ & $232.42 \pm 7.37^{\mathrm{d}}$ & $275.28 \pm 5.57^{c}$ & $224.05 \pm 6.32 \mathrm{e}$ & $344.05 \pm 5.87^{a}$ \\
\hline V57 & Safrole & $94-59-7$ & 1628 & $12.59 \pm 0.51 \mathrm{bc}$ & $14.59 \pm 0.45^{\mathrm{ab}}$ & $8.91 \pm 0.68^{\mathrm{d}}$ & $10.48 \pm 0.75^{\mathrm{cd}}$ & $13.99 \pm 0.65^{\mathrm{ab}}$ & $15.97 \pm 1.34^{\mathrm{a}}$ \\
\hline V58 & Eugenol & $97-53-0$ & 2141 & $240.48 \pm 6.94^{a}$ & $187.47 \pm 5.33^{b}$ & $136.75 \pm 5.46^{c}$ & $140.72 \pm 4.47^{c}$ & $148.83 \pm 5.12^{c}$ & $231.42 \pm 6.27^{\mathrm{a}}$ \\
\hline \multirow[t]{2}{*}{ V59 } & Methyl eugenol & $93-15-2$ & 1755 & $5.89 \pm 0.24^{c}$ & $8.00 \pm 0.37^{\mathrm{b}}$ & $2.49 \pm 0.08^{\mathrm{d}}$ & $3.38 \pm 0.13^{d}$ & $6.78 \pm 0.34^{c}$ & $14.27 \pm 0.55^{\mathrm{a}}$ \\
\hline & Total & & & $750.87 \pm 10.83^{b}$ & $634.81 \pm 19.57^{c}$ & $504.18 \pm 6.86^{\mathrm{e}}$ & $584.15 \pm 5.57^{d}$ & $559.34 \pm 7.57^{\mathrm{d}}$ & $821.42 \pm 12.30^{\mathrm{a}}$ \\
\hline
\end{tabular}

Different lowercase letters (a-f) within the same row indicate significant differences among the different treatments $(p<0.05)$. n.d.: not detected. LRI: linear retention index. CAS: the unique numerical identification number for substance specified by the Chemical Abstracts Service. CT: $2.50 \% \mathrm{NaCl} ; \mathrm{CR}: 1.75 \% \mathrm{NaCl} ; \mathrm{PK}: 1.75 \% \mathrm{NaCl}+P$. kudriavzevii; TD: $1.75 \% \mathrm{NaCl}+$ T. delbrueckii; $\mathrm{DH}: 1.75 \% \mathrm{NaCl}+$ D. hansenii.

Four aldehydes (hexanal, nonanal, tridecanal, and cinnamaldehyde) were identified in the dry sausages. Since hexanal and nonanal are derived from the oxidation of $n-6$ and n-9 polyunsaturated fatty acid oxidation [48], respectively, they gradually accumulated during the 12-day fermentation period and became the two most abundant aldehydes in the sausages. Hexanal, a typical indicator to evaluate lipid oxidation levels [49] that imparts grass, tallow, and fat flavours to meat products [50], was significantly higher in the PK and DH treatments compared to the controls $(p<0.05)$. Tridecanal, which is linked to floral and sweet flavours, was present in all sausages but its content increased significantly in yeast-inoculated sausages $(p<0.05)$, which is due to lipid oxidation [51].

Ketones are derived from the microbial enzymatic breakdown of lipids or amino acids or by the Maillard reaction [52]. A total of five ketones were detected in the sausages, of which only 3-hydroxy-2-butanone and 2-nonanone were detected in all sausages. 3Hydroxy-2-butanone is derived from carbohydrate metabolism, whereas 2-nonanone is derived from lipid beta-oxidation. These two methyl ketones are considered characteristic fermented flavour compounds [47]. However, yeast inoculation did not affect the contents of these compounds in the sausages regardless of treatment $(p>0.05)$.

A total of 12 alcohols were detected, which originated from carbohydrate metabolism, reduction of methyl ketones and aldehydes, amino acid metabolism, and lipid oxidation [53,54]. Ethanol, a common alcohol in dry fermented sausages, mainly comes from the wine that is added during sausage preparation. However, this compound can accumulate via the 
alcoholic fermentation of glucose or the pentose-phosphate route [53]. Ethanol levels remained higher than those of other alcohols throughout the fermentation process but decreased significantly after fermentation (except in the DH treatment), which was likely due to its conversion to esters via interaction with acids [55]. The ethanol content increased significantly in the DH treatment $(p<0.05)$ and the same phenomenon was also confirmed in 'salchichón' sausages after inoculation with D. hansenii [56], which was likely due to the strong ability of $D$. hansenii to produce alcohols from the metabolism of carbohydrates and branched-chain amino acids [57]. Furthermore, 1-octen-3-ol is an odorant with a mushroom-like flavour that is usually present in meat products [54]. The content of this compound increased significantly after fermentation $(p<0.05)$. On day 12 , the PK, TD, and $\mathrm{DH}$ treatments exhibited higher content compared to the controls $(p<0.05)$. Further, some alcohols from spices such as linalool and cineole provide dry sausages with characteristic citrus and herbal odours, respectively, and are also important aroma compounds.

Six acids were found in dry sausages, of which acetic and butanoic acids were derived from carbohydrate fermentation, whereas octanoic and nonanoic acids were derived from lipid oxidation [58]. Acids were represented mainly by acetic acid, which can contribute to the typical aroma of meat products, especially dry fermented products [59]. In the present study, the content of acetic acid significantly increased after 12 days of fermentation $(p<0.05)$ and the content of acetic acid was significantly higher in the CR treatment on day $12(p<0.05)$, indicating that the lower salt content could promote the production of acetic acid. Among the inoculated sausages, the contents of all acids in the DH treatment were significantly higher than that in the CT and CR treatments $(p<0.05)$. Increases in heptanoic acid and nonanoic acid were found in the PK treatment, and an increase in heptanoic acid was found in the TD treatment $(p<0.05)$. Nevertheless, despite being ester precursors, acids are generally non-essential aroma contributors due to their high odour thresholds.

Esters are crucial contributors to the unique odour profile of dry sausages and generally originate from the non-enzymatic esterification of alcohols and acids, as well as enzymatic catalysis by microorganisms [60]. Most of the esters identified in the present study were ethyl esters, which impart fruity aromas and mask unpleasant odours [48]. These compounds included ethyl acetate, ethyl lactate, ethyl butyrate, ethyl hexanoate, ethyl heptanoate, ethyl caprylate, and ethyl caprate. After 12 days of fermentation, the total ester contents increased in all treatments and each treatment exhibited a unique ester profile. Among the inoculated sausages, the DH treatment showed the highest total ester content at $340.44 \mu \mathrm{g} / \mathrm{kg}$, followed by the PK and TD treatments, reaching 194.93 and $192.77 \mu \mathrm{g} / \mathrm{kg}$, respectively, suggesting that yeast inoculation can promote the production of esters that could positively affect the dry sausage aroma. The same phenomenon has been reported in different meat products, such as fermented sausages [56], dry-cured ham [61], and cured pork [46]. However, these effects depend largely on the genus and species of the inoculated yeasts.

A total of 15 terpenes and six other compounds were detected, most of which were not related to chemical or biological processes, but may be related to the spices added during sausage preparation. As a result of the fermentation process, the contents of some compounds [sabinene, $\gamma$-terpinene, (1S)-(1)- $\beta$-pinene and 3 -carene] from spices increased to various degrees.

\subsection{PLS-DA of Volatile Compounds}

PLS-DA was performed to explore the differences of the volatiles in reduced-salt sausages inoculated with different yeast strains and to clarify the dynamics changes in these volatiles before and after fermentation. Figure 3A shows the classification pattern of dry sausages by the PLS-DA model with variance explanation $52.8 \%$ and $33.7 \%$ of component 1 and component 2, respectively. The score plot of the PLS-DA model showed that the six treatments were segregated well from each other. Among them, the CT sausages at days 0 and 12 were clustered on the left side of the score plot, while the CR, PK, TD and $\mathrm{DH}$ sausages at day 12 were clustered on the right side of the score plot. 
(A)

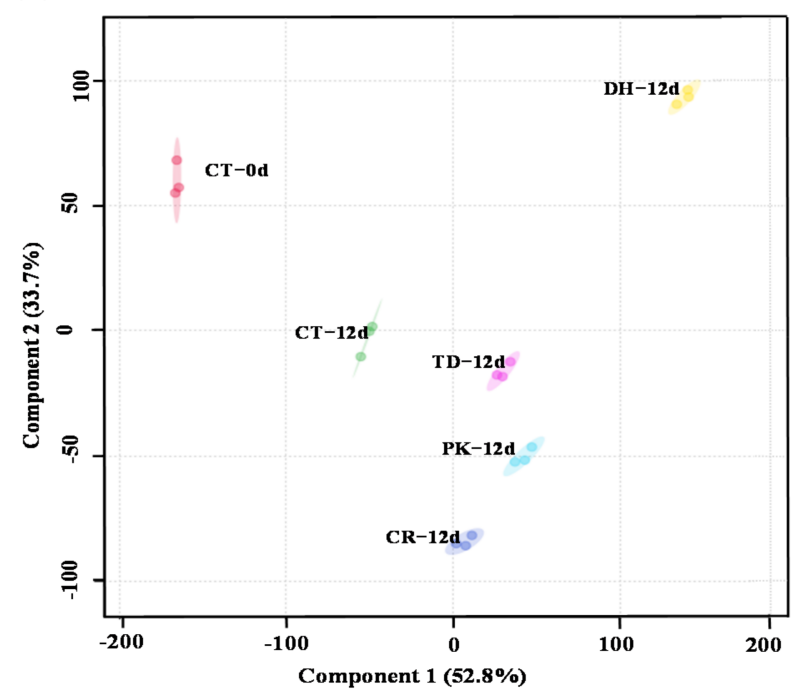

(B)

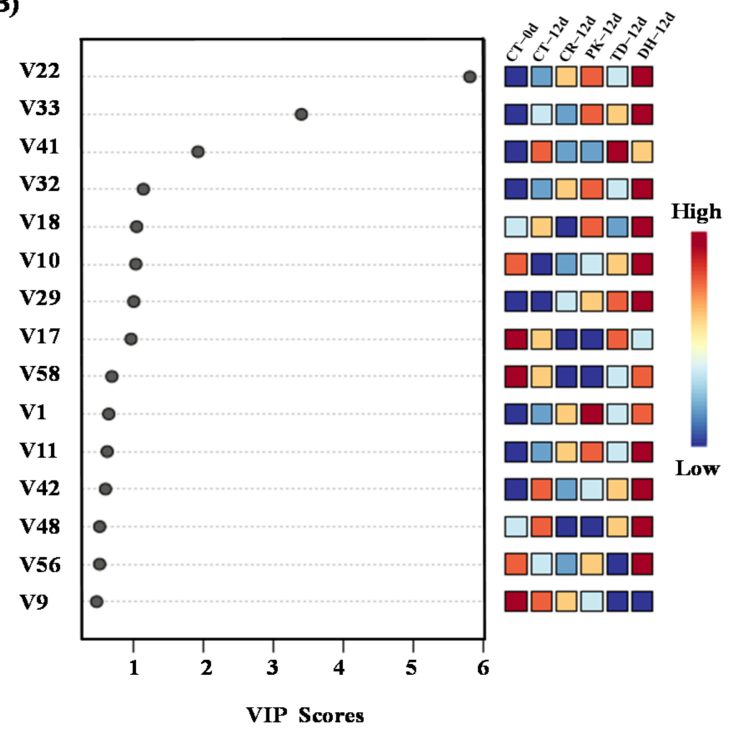

Figure 3. Partial least squares-discriminant analysis score plot (A) and the top 15 variables important in the projection (VIP) values (B) of all volatile compounds for the control and reduced-salt dry sausages with and without yeast inoculation on days 0 and 12. V9-V58: the numbers of the corresponding volatile compounds in Table 5. CT: $2.50 \% \mathrm{NaCl}$; CR: $1.75 \% \mathrm{NaCl} ; \mathrm{PK}: 1.75 \% \mathrm{NaCl}+$ P. kudriavzevii; TD: $1.75 \% \mathrm{NaCl}+$ T. delbrueckii; $\mathrm{DH}: 1.75 \% \mathrm{NaCl}+$ D. hansenii.

Variable importance in prediction (VIP) can be used to assess the influence strength and explanatory ability of each variable on classification and identification, in which the variable with VIP $>1$ is considered to play a significant role [58,59]. Figure 3B showed the 15 top differential volatile compounds, including one acid (acetic acid), two alcohols (linolool and ethanol), three esters (ethyl hexanoate, methyl hexanaoate, and ethyl lactate), and one terpene [(+)-dipentene] with VIP values $>1$ were identified as potential classification compounds for the different dry sausages. The higher the VIP value, the greater difference of the aroma compounds between groups, and more important to the discrimination of the aroma types of dry sausages [62]. Notably, inoculation with D. hansenii significantly increased the content of six differential compounds [except (+)-dipentene] compared to the CR treatment, while inoculation with P. kudriavzevii significantly increased the content of five differential compounds [except (+)-dipentene and ethyl hexanoate]. Inoculation with T. delbrueckii only had a significant elevating effect on the content of ethanol, ethyl lactate, and (+)-dipentene compared to the CR treatment, implying that the flavour profiles varied depending on the yeast strains used.

\subsection{Sensory Evaluation}

Table 6 summarizes the results of the sensory evaluation, including colour, hardness, aroma, sourness, saltiness, and umami. There was no significant difference in the colour score $(p>0.05)$; however, this was not consistent with the instrumental colour measurement results, which are more accurate than sensory evaluation. In terms of hardness, the PK treatment score was significantly lower than that of the controls $(p<0.05)$, which was in line with the shear force analysis results. Moreover, the aroma scores of the inoculated treatments were significantly higher than those of the controls $(p<0.05)$. This may be associated with the higher abundance of volatiles detected in the inoculated treatments. In terms of taste, the DH and PK treatments had higher saltiness scores, and the PK treatment presented higher umami scores which were consistent with the electronic tongue analysis results. In contrast, there were no significant differences in the sourness of the dry sausages $(p>0.05)$, which may be because the change in the acidity of the dry sausages was not enough to affect their perceived sourness. Combining these results, we concluded 
that D. hansenii and P. kudriavzevii inoculation can compensate for the flavour deficiencies of reduced-salt dry sausages.

Table 6. Sensory evaluation of the control and reduced-salt dry sausages with and without yeast inoculation after a 12-day fermentation period.

\begin{tabular}{cccccc}
\hline Attribute & CT & CR & PK & TD & DH \\
\hline Colour & $5.52 \pm 0.33^{\mathrm{a}}$ & $5.15 \pm 0.26^{\mathrm{a}}$ & $5.32 \pm 0.43^{\mathrm{a}}$ & $5.18 \pm 0.33^{\mathrm{a}}$ & $5.48 \pm 0.38^{\mathrm{a}}$ \\
Hardness & $6.23 \pm 0.42^{\mathrm{a}}$ & $5.53 \pm 0.35^{\mathrm{ab}}$ & $4.33 \pm 0.45^{\mathrm{c}}$ & $5.47 \pm 0.31^{\mathrm{ab}}$ & $4.83 \pm 0.15^{\mathrm{bc}}$ \\
Amora & $4.83 \pm 0.25^{\mathrm{b}}$ & $4.80 \pm 0.46^{\mathrm{b}}$ & $5.73 \pm 0.31^{\mathrm{a}}$ & $5.97 \pm 0.25^{\mathrm{a}}$ & $6.30 \pm 0.20^{\mathrm{a}}$ \\
Sourness & $4.37 \pm 0.40^{\mathrm{a}}$ & $4.60 \pm 0.26^{\mathrm{a}}$ & $4.43 \pm 0.25^{\mathrm{a}}$ & $4.40 \pm 0.30^{\mathrm{a}}$ & $4.47 \pm 0.21^{\mathrm{a}}$ \\
Saltiness & $5.60 \pm 0.30^{\mathrm{a}}$ & $3.27 \pm 0.31^{\mathrm{c}}$ & $4.20 \pm 0.26^{\mathrm{b}}$ & $3.33 \pm 0.32^{\mathrm{c}}$ & $4.40 \pm 0.26^{\mathrm{b}}$ \\
Umami & $5.07 \pm 0.35^{\mathrm{a}}$ & $4.60 \pm 0.26^{\mathrm{ab}}$ & $4.97 \pm 0.31^{\mathrm{a}}$ & $4.33 \pm 0.25^{\mathrm{ab}}$ & $4.07 \pm 0.25^{\mathrm{b}}$ \\
\hline
\end{tabular}

Different lowercase letters $(\mathrm{a}-\mathrm{c})$ within a row indicate significant differences among the different treatments $(p<0.05)$. CT: $2.50 \%$ NaCl; CR: $1.75 \%$ NaCl; PK: $1.75 \% \mathrm{NaCl}+$ P. kudriavzevii; TD: $1.75 \% \mathrm{NaCl}+$ T. delbrueckii; $\mathrm{DH}$ $1.75 \% \mathrm{NaCl}+$ D. hansenii.

Based on the above analysis, it was speculated that the complex microbial enzymes involved in relevant the enzymatic breakdown of carbohydrates, proteins and lipids that affect colour, flavour and texture may be important to improve the quality characteristics of reduced-salt dry sausages. Previous studies have purified a variety of endo- and exo-peptidases from yeast which facilitate the production of FAAs and peptides in meat products [63], which were the flavour compounds and the precursors of flavour compounds. Particularly, some FAAs and peptides can provide saltiness and umami and thus may enhance the taste properties of reduced-salt dry sausages [23]. In addition, a glutaminase that purified from $D$. hansenii was able to neutralize the acid $\mathrm{pH}$ of fermented sausages and

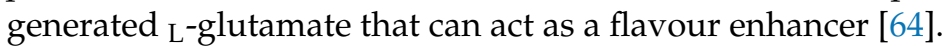

\section{Conclusions}

Our results indicated that yeast inoculation has different effects on the physical, microbial and flavour characteristics of dry sausages. D. hansenii inoculation increased the moisture content and $L^{*}$-value, whereas all three yeast strains reduced hardness. Additionally, both salt reduction and yeast inoculation changed the flavour profiles (taste and odour properties) of dry sausages. Yeast inoculation, particularly P. kudriavzevii and D. hansenii, compensated for the saltiness and umami of reduced-salt sausages. Furthermore, yeast inoculation promoted the formation of volatile compounds (mainly alcohol, esters, terpenes, and some acids) and enhanced the sensory quality of reduced-salt dry sausages. In conclusion, $P$. kudriavzevii and D. hansenii are effective starter cultures that can compensate for the quality and flavour deficiencies of reduced-salt dry sausages.

Author Contributions: Data curation, writing-original draft preparation and visualization, X.-A.L.; conceptualization, writing-reviewing and editing, B.K.; conceptualization and methodology, R.W.; investigation and formal analysis, H.W.; visualization and software, M.L.; investigation and formal analysis, and funding acquisition, Q.C. All authors have read and agreed to the published version of the manuscript.

Funding: This study was funded by the National Natural Science Foundation of China (32172232 and 31972139) and the Major Science and Technology Projects of Heilongjiang Province (2021ZX12B05).

Institutional Review Board Statement: Not applicable.

Informed Consent Statement: Not applicable.

Data Availability Statement: The data presented in this study are available within the article.

Conflicts of Interest: The authors declare no conflict of interest. 


\section{References}

1. Gullón, P.; Astray, G.; Gullón, B.; Franco, D.; Campagnol, P.C.B.; Lorenzo, M.J. Inclusion of seaweeds as healthy approach to formulate new low-salt meat products. Curr. Opin. Food Sci. 2021, 40, 20-25. [CrossRef]

2. Mariutti, L.R.B.; Bragagnolo, N. Influence of salt on lipid oxidation in meat and seafood products: A review. Food Res. Int. 2017, 94, 90-100. [CrossRef] [PubMed]

3. Zheng, J.B.; Han, Y.R.; Ge, G.; Zhao, M.M.; Sun, W.Z. Partial substitution of $\mathrm{NaCl}$ with chloride salt mixtures: Impact on oxidative characteristics of meat myofibrillar protein and their rheological properties. Food Hydrocoll. 2019, 96, 36-42. [CrossRef]

4. Cook, N.R.; Cutler, J.A.; Obarzanek, E.; Buring, J.E.; Rexrode, K.M.; Kumanyika, S.K.; Appel, L.J.; Whelton, P.K. Long term effects of dietary sodium reduction on cardiovascular disease outcomes: Observational follow-up of the trials of hypertension prevention (TOHP). BMJ Brit. Med. J. 2007, 334, 1-8. [CrossRef]

5. He, F.J.; Jenner, K.H.; MacGregor, G.A. WASH-World action on salt and health. Kidney Int. 2010, 78, 745-753. [CrossRef] [PubMed]

6. Quilaqueo, M.; Duizer, L.; Aguilera, J.M. The morphology of salt crystals affects the perception of saltiness. Food Res. Int. 2015, 76, 675-681. [CrossRef] [PubMed]

7. World Health Organization (WHO). Guideline: Sodium Intake for Adults and Children; World Health Organization: Geneva, Switzerland, 2012.

8. Campagnol, P.C.B.; dos Santos, B.A.; Wanger, R.; Terra, N.N.; Pollonio, M.A.R. The effect of yeast extract addition on quality of fermented sausages at low $\mathrm{NaCl}$ content. Meat Sci. 2011, 87, 290-298. [CrossRef] [PubMed]

9. Wen, R.X.; Hu, Y.Y.; Zhang, L.; Wang, Y.; Chen, Q.; Kong, B.H. Effect of $\mathrm{NaCl}$ substitutes on lipid and protein oxidation and flavor development of Harbin dry sausage. Meat Sci. 2019, 156, 33-43. [CrossRef]

10. Hu, Y.Y.; Zhang, L.; Zhang, H.; Wang, Y.; Chen, Q.; Kong, B.H. Physicochemical properties and flavour profile of fermented dry sausages with a reduction of sodium chloride. LWT Food Sci. Technol. 2020, 124, 109061. [CrossRef]

11. Toldrá, F. The role of muscle enzymes in dry-cured meat products with different drying conditions. Trends Food Sci. Technol. 2006, 17, 164-168. [CrossRef]

12. Corral, S.; Belloch, C.; López-Díez., J.J.; Salvador, A.; Flores, M. Yeast inoculation as a strategy to improve the physico-chemical and sensory properties of reduced salt fermented sausages produced with entire male fat. Meat Sci. 2017, 123, 1-7. [CrossRef] [PubMed]

13. Inguglia, E.S.; Zhang, Z.H.; Tiwaria, B.K.; Kerry, J.P.; Burgess, C.M. Salt reduction strategies in processed meat products-A review. Trends Food Sci. Technol. 2017, 59, 70-78. [CrossRef]

14. Zanardi, E.; Ghidini, S.; Conter, M.; Lanieri, A. Mineral composition of Italian salami and effect of NaCl partial replacement on compositional, physico-chemical and sensory parameters. Meat Sci. 2010, 86, 742-747. [CrossRef]

15. Talon, R.; Leroy, S. Diversity and safety hazards of bacteria involved in meat fermentations. Meat Sci. 2011, 89, 303-309. [CrossRef] [PubMed]

16. Dos Santos Cruxen, C.E.; Funck, G.D.; Haubert, L.; da Silva Dannenberg, G.; de Lima Marques, J.; Chaves, F.C.; da Sliva, W.P. Selection of native bacterial starter culture in the production of fermented meat sausages: Application potential, safety aspects, and emerging technologies. Food Res. Int. 2019, 122, 371-382. [CrossRef]

17. Flores, M.; Corral, S.; Cano-García, L.; Salvador, A.; Belloch, C. Yeast strains as potential aroma enhancers in dry fermented sausages. Int. J. Food Microbiol. 2015, 212, 16-24. [CrossRef]

18. Gardini, F.; Suzzi, G.; Lombardi, A.; Galgano, F.; Crudele, M.A.; Andrighetto, C.; Schirone, M.; Tofalo, R. A survey of yeasts in traditional sausages of southern Italy. FEMS Yeast Res. 2001, 1, 161-167. [CrossRef]

19. Flores, M.; Durá, M.-A.; Marco, A.; Toldrá, F. Effect of Debaryomyces spp. on aroma formation and sensory quality of dry-fermented sausages. Meat Sci. 2004, 68, 439-446. [CrossRef]

20. Copetti, M.V. Yeasts and molds in fermented food production: An ancient bioprocess. Curr. Opin. Food Sci. 2019, 25, 57-61. [CrossRef]

21. Andrade, M.J.; Thorsen, L.; Rodríguez, A.; Córdoba, J.J.; Jespersen, L. Inhibition of ochratoxigenic moulds by Debaryomyces hansenii strains for biopreservation of dry-cured meat products. Int. J. Food Microbiol. 2014, 170, 70-77. [CrossRef]

22. Chen, Q.; Kong, B.H.; Han, Q.; Liu, Q.; Xu, L. The role of bacterial fermentation in the hydrolysis and oxidation of sarcoplasmic and myofibrillar proteins in Harbin dry sausages. Meat Sci. 2016, 121, 196-206. [CrossRef] [PubMed]

23. Hu, Y.Y.; Li, Y.J.; Zhu, J.M.; Kong, B.H.; Liu, Q.; Chen, Q. Improving the taste profile of reduced-salt dry sausage by inoculating different lactic acid bacteria. Food Res. Int. 2021, 145, 110391. [CrossRef] [PubMed]

24. Wen, R.X.; Sun, F.D.; Li, X.A.; Chen, Q.; Kong, B.H. The potential correlations between the fungal communities and volatile compounds of traditional dry sausages from Northeast China. Food Microbiol. 2021, 98, 103787. [CrossRef] [PubMed]

25. Wen, R.X.; Yin, X.Y.; Hu, Y.Y.; Chen, Q.; Kong, B.H. Technological properties and flavour formation potential of yeast strains isolated from traditional dry fermented sausages in Northeast China. LWT Food Sci. Technol. 2021, 154, 112853. [CrossRef]

26. Williams, S. Association of Official Methods of Analysis Methods 925.04, 16th ed.; Association of Official Analytical Chemists (AOAC): Arlington, VA, USA, 1995.

27. Hu, Y.Y.; Wang, H.; Kong, B.H.; Wang, Y.; Chen, Q. The succession and correlation of the bacterial community and flavour characteristics of Harbin dry sausages during fermentation. LWT Food Sci. Technol. 2021, 138, 110689. [CrossRef]

28. Wen, R.X.; Lv, Y.C.; Li, X.A.; Chen, Q.; Kong, B.H. High-throughput sequencing approach to reveal the bacterial diversity of traditional yak jerky from the Tibetan regions. Meat Sci. 2021, 172, 108348. [CrossRef] 
29. Bolumar, T.; Sanz, Y.; Flores, M.; Aristoy, M.C.; Toldrá, F.; Flores, J. Sensory improvement of dry-fermented sausages by the addition of cell-free extracts from Debaryomyces hansenii and Lactobacillus sakei. Meat Sci. 2006, 72, 457-466. [CrossRef]

30. Hu, Y.Y.; Li, Y.J.; Li, X.A.; Zhang, H.; Chen, Q.; Kong, B.H. Application of lactic acid bacteria for improving the quality of reduced-salt dry fermented sausage: Texture, color, and flavor profiles. LWT Food Sci. Technol. 2022, 154, 112723. [CrossRef]

31. Yin, X.Y.; Du, H.Z.; Xu, M.; Chen, Q.; Kong, B.H. Heterocyclic aromatic amine level and quality characteristics of selected Harbin red sausages in the northern Chinese market. Meat Sci. 2021, 172, 108360. [CrossRef]

32. Zhang, L.; Hu, Y.Y.; Wang, Y.; Kong, B.H.; Chen, Q. Evaluation of the flavour properties of cooked chicken drumsticks as affected by sugar smoking times using an electronic nose, electronic tongue, and HS-SPME/GC-MS. LWT Food Sci. Technol. 2021, 140, 110764. [CrossRef]

33. Chen, Q.; Hu, Y.Y.; Wen, R.X.; Wang, Y.; Qin, L.G.; Kong, B.H. Characterisation of the flavour profile of dry fermented sausages with different $\mathrm{NaCl}$ substitutes using HS-SPME-GC-MS combined with electronic nose and electronic tongue. Meat Sci. 2021, 172, 108338. [CrossRef] [PubMed]

34. Chen, J.X.; Hu, Y.Y.; Wen, R.X.; Liu, Q.; Chen, Q.; Kong, B.H. Effect of NaCl substitutes on the physical, microbial and sensory characteristics of Harbin dry sausage. Meat Sci. 2019, 156, 205-213. [CrossRef]

35. Perea-Sanz, L.; López-Díez, J.J.; Belloch, C.; Flores, M. Counteracting the effect of reducing nitrate/nitrite levels on dry fermented sausage aroma by Debaryomyces hansenii inoculation. Meat Sci. 2020, 164, 108103. [CrossRef] [PubMed]

36. Karabagias, I.; Badeka, A.; Kontominas, M.G. Shelf life extension of lamb meat using thyme or oregano essential oils and modified atmosphere packaging. Meat Sci. 2011, 88, 109-116. [CrossRef] [PubMed]

37. García, C.; Rendueles, M.; Díaz, M. Liquid-phase food fermentations with microbial consortia involving lactic acid bacteria: A review. Food Res. Int. 2019, 119, 207-220. [CrossRef] [PubMed]

38. Oh, H.; Lee, H.J.; Lee, J.Y.; Jo, C.; Yoon, Y. Identification of microorganisms associated with the quality improvement of dry-aged beef through microbiome analysis and DNA sequencing, and evaluation of their effects on beef quality. J. Food Sci. 2019, 84, 2944-2954. [CrossRef] [PubMed]

39. Marušić, N.; Petrović, M.; Vidaček, S.; Petrak, T.; Medić, H. Characterization of traditional lstrian dry-cured ham by means of physical and chemical analyses and volatile compounds. Meat Sci. 2011, 88, 786-790. [CrossRef]

40. Murgia, M.A.; Marongiu, A.; Aponteb, M.; Blaiotta, G.; Deiana, P.; Mangia, N.P. Impact of a selected Debaryomyces hansenii strain's inoculation on the quality of Sardinian fermented sausages. Food Res. Int. 2019, 121, 144-150. [CrossRef] [PubMed]

41. Ramos-Moreno, L.; Ruiz-Pérez, F.; Rodríguez-Castro, E.; Ramos, J. Debaryomyces hansenii Is a real tool to improve a diversity of characteristics in sausages and dry-meat products. Microorganisms 2021, 9, 1512. [CrossRef]

42. Liu, P.X.; Wang, S.W.; Zhang, H.; Wang, H.T.; Kong, B.H. Influence of glycated nitrosohaemoglobin prepared from porcine blood cell on physicochemical properties, microbial growth and flavour formation of Harbin dry sausages. Meat Sci. 2019, 148, 96-104. [CrossRef]

43. Xia, X.F.; Kong, B.H.; Liu, Q.; Liu, J. Physicochemical change and protein oxidation in porcine longissimus dorsi as influenced by different freeze-thaw cycles. Meat Sci. 2009, 83, 239-245. [CrossRef]

44. Ali, M.M.; Hashim, N.; Aziz, S.A.; Lasekan, O. Principles and recent advances in electronic nose for quality inspection of agricultural and food products. Trends Food Sci. Technol. 2020, 99, 1-10. [CrossRef]

45. Ramos-Moreno, L.; Ruiz-Castilla, F.J.; Bravo, C.; Martínez, E.; Menéndez, M.; Dios-Palomares, R.; Ramos, J. Inoculation with a terroir selected Debaryomyces hansenii strain changes physico-chemical characteristics of Iberian cured pork loin. Meat Sci. 2019, 157, 107875. [CrossRef]

46. Alim, A.; Song, H.L.; Liu, Y.; Zou, T.T.; Zhang, Y.; Zhang, S.P. Flavor-active compounds in thermally treated yeast extracts. J. Sci. Food Agric. 2018, 98, 3774-3783. [CrossRef] [PubMed]

47. Chen, Q.; Kong, B.; Han, Q.; Xia, X.F.; Xu, L. The role of bacterial fermentation in lipolysis and lipid oxidation in Harbin dry sausages and its flavour development. LWT Food Sci. Technol. 2017, 77, 389-396. [CrossRef]

48. Zhou, H.M.; Zhao, B.; Zhang, S.L.; Wu, Q.R.; Zhu, N.; Li, S.; Pan, X.; Wang, S.W.; Qiao, X.L. Development of volatiles and odor-active compounds in Chinese dry sausage at different stages of process and storage. Food Sci. Hum. Well. 2021, 10, 316-326. [CrossRef]

49. Gómez, M.; Lorenzo, J.M. Effect of fat level on physicochemical, volatile compounds and sensory characteristics of dry-ripened "chorizo" from Celta pig breed. Meat Sci. 2013, 95, 658-666. [CrossRef]

50. Azarbad, M.H.; Jeleń, H. Determination of hexanal-an indicator of lipid oxidation by static headspace gas chromatography (SHS-GC) in fat-rich food matrices. Food Anal. Methods 2014, 8, 1727-1733. [CrossRef]

51. Wang, F.; Gao, Y.Q.; Wang, H.B.; Xi, B.; He, X.N.; Yang, X.L.; Li, W.H. Analysis of volatile compounds and flavor fingerprint in Jingyuan lamb of different ages using gas chromatography-Ion mobility spectrometry (GC-IMS). Meat Sci. 2021, 175, 108449. [CrossRef]

52. Pongsetkul, J.; Benjakul, S.; Vongkamjan, K.; Sumpavapol, P.; Osako, K.; Faithong, N. Changes in volatile compounds, ATP-related compounds and antioxidative properties of Kapi, produced from Acetes vulgaris, during processing and fermentation. Food Biosci. 2017, 19, 49-56. [CrossRef]

53. De Lima Alves, L.; Donadel, J.Z.; Athayde, D.R.; da Silva, M.S.; Klein, B.; Fagundes, M.B.; de Menezes, C.R.; Barin, J.S.; Campagnol, P.C.B.; Wagner, R.; et al. Effect of ultrasound on proteolysis and the formation of volatile compounds in dry fermented sausages. Ultrason. Sonochem. 2020, 67, 105161. [CrossRef] 
54. Sidira, M.; Kandylis, P.; Kanellaki, M.; Kourkoutas, Y. Effect of curing salts and probiotic cultures on the evolution of flavor compounds in dry-fermented sausages during ripening. Food Chem. 2016, 15, 334-338. [CrossRef]

55. Zhong, A.; Chen, W.; Duan, Y.; Li, K.; Tang, X.; Tian, X.; Wu, Z.; Li, Z.; Wang, Y.; Wang, C. The potential correlation between microbial communities and flavors in traditional fermented sour meat. LWT Food Sci. Technol. 2021, 149, 111873. [CrossRef]

56. Andrade, M.J.; Córdoba, J.J.; Casado, E.M.; Córdoba, M.G.; Rodríguez, M. Effect of selected strains of Debaryomyces hansenii on the volatile compound production of dry fermented sausage "salchichón". Meat Sci. 2010, 85, 256-264. [CrossRef]

57. Olesen, P.T.; Stahnke, L.H. The influence of Debaryomyces hansenii and Candida utilis on the aroma formation in garlic spiced fermented sausages and model minces. Meat Sci. 2000, 56, 357-368. [CrossRef]

58. Hu, Y.Y.; Zhang, L.; Liu, Q.; Wang, Y.; Chen, Q.; Kong, B.H. The potential correlation between bacterial diversity and the characteristic volatile flavour of traditional dry sausages from Northeast China. Food Microbiol. 2020, 91, 103505. [CrossRef] [PubMed]

59. Montanari, C.; Gatto, V.; Torriani, S.; Barbieri, F.; Bargossi, E.; Lanciotti, R.; Grazia, L.; Magnani, R.; Tabanelli, G.; Gardini, F. Effects of the diameter on physico-chemical, microbiological and volatile profile in dry fermented sausages produced with two different starter cultures. Food Biosci. 2018, 22, 9-18. [CrossRef]

60. Landaud, S.; Sandra, H.; Pascal, B. Formation of volatile sulfur compounds and metabolism of methionine and other sulfur compounds in fermented food. Appl. Microbiol. Biot. 2008, 77, 1191-1205. [CrossRef] [PubMed]

61. Martín, A.; Córdoba, J.J.; Aranda, E.; Córdoba, M.G.; Asensio, M.A. Contribution of a selected fungal population to the volatile compounds on dry-cured ham. Int. J. Food Microbiol. 2006, 110, 8-18. [CrossRef]

62. Feng, X.Y.; Wang, H.W.; Wang, Z.R.; Huang, P.M.; Kan, J.Q. Discrimination and characterization of the volatile organic compounds in eight kinds of huajiao with geographical indication of China using electronic nose, HS-GC-IMS and HS-SPME-GC-MS. Food Chem. 2022, 375, 131671. [CrossRef]

63. Flores, M.; Toldrá, F. Microbial enzymatic activities for improved fermented meats. Trends Food Sci. Technol. 2011, 22, 81-90. [CrossRef]

64. Durá, M.A.; Flores, M.; Toldrá, F. Purification and characterisation of a glutaminase from Debaryomyces spp. Int. J. Food Microbiol 2002, 76, 117-126. [CrossRef] 